\title{
ÇEVRESEL SORUNLARA KARŞI ÇÖZÜM ÖNERİLERİ: GÜNCEL SÜRDÜRÜLEBIILİR BESLENME UYGULAMALARINA GENEL BAKIŞ
}

\author{
Başak Can, Hatice Merve Bayram, S. Arda Öztürkcan* \\ İstanbul Gelişim Üniversitesi, Sağlık Bilimleri Fakültesi, Beslenme ve Diyetetik Bölümü, İstanbul, Türkiye \\ Geliş / Received: 24.03.2021; Kabul / Accepted: 29.07.2021; Online bask1 / Published online: 24.08.2021
}

Can, B., Bayram, H.M., Öztürkcan, S.A. (2021). Çevresel sorunlara karşı çözüm önerileri: güncel sürdürülebilir beslenme uygulamalarına genel bakış. GIDA (2021) 46 (5) 1138-1157 doi: 10.15237/gida.GD21062.

Can, B., Bayram, H.M., Öztürkcan, S.A. (2021). Solution recommendations for environmental problems: overview of current sustainable nutrition practices. GIDA (2021) 46 (5) 1138-1157 doi: 10.15237/gida.GD21062.

\section{ÖZ}

Günümüzde dünya nüfusunun artması ile birlikte insanlığın, kaynakların tükenme tehlikesi ile karşı karşıya kalması beklenmektedir. "Sürdürülebilir Beslenme" kavramının amaçlarından biri kaynakların gelecek kuşaklara aktarılabilmesidir. Bunun için yapılabileceklerin başında geleneksel beslenme modellerini ve beslenme alışkanlıklarını; çevreye ve sağlığa yararlı beslenme modelleri ve alışkanlıkları ile değiştirmek gelmektedir. Bunun yanı sıra sürdürülebilir beslenme için besin ögesi içerikleri hayvansal protein kaynaklı besinlere yakın olan, herkes tarafindan erişilebilir ve kabul görebilecek alternatif protein kaynakları bulmak önemlidir. Son yıllarda ülkemizde bu kavramın önemi artmış durumdadır. Bu derlemenin amacı, sürdürülebilir beslenme ve çevresel etki açısından devamlılığı en fazla olan bitkisel kaynaklı besinleri temel alan beslenme modelleri ile gelecek yüzyllarda sera gazı etkisini azaltmak için tüketilebilecek alternatif protein kaynakları hakkında insanların bilinç düzeyini artırmak adına kapsamlı bilgi sunmaktır.

Anahtar kelimeler: Sürdürülebilirlik, sürdürülebilir beslenme, sera gazı emisyonu, alternatif protein kaynakları, Akdeniz tipi beslenme

\section{SOLUTION RECOMMENDATIONS FOR ENVIRONMENTAL PROBLEMS: OVERVIEW OF CURRENT SUSTAINABLE NUTRITION PRACTICES}

\begin{abstract}
Due to the increasing world population today, it is expected that humanity will face the danger of depletion of resources. One of the aims of "Sustainable Nutrition" is to transfer resources to future generations. At the beginning of what can be done for this, traditional nutrition models and eating habits; change with environmental and health-beneficial eating patterns and habits. Additionally, for sustainable nutrition, it is important to find alternative protein sources that nutritional contents are close to animal protein-based foods, accessible and acceptable by everyone. In recent years, the importance of this concept has increased in our country. This review aims to provide comprehensive information to increase the awareness of people about alternative protein sources that can be consumed to reduce greenhouse gas emissions effect in the coming centuries with nutrition models
\end{abstract}

\footnotetext{
${ }^{*}$ Yazışmalardan sorumlu yazar / Corresponding author

17: sozturkcan@gelisim.edu.tr
}

Başak Can; ORCID no: 0000-0002-0608-6496

Hatice Merve Bayram; ORCID no: 0000-0002-7073-2907

S. Arda Öztürkcan; ORCID no: 0000-0001-7982-6988 
based on plant-based foods, which are the highest sustainability in terms of sustainable nutrition and environmental impact.

Keywords: Sustainability, sustainable nutrition, greenhouse gas emissions, alternative protein sources, Mediterranean diet

\section{GİRIŞ}

20. yüzylldan bu yana dünya nüfusu gün geçtikçe hızlı bir şekilde artmaktadır. Bu artışa bağlı olarak günümüzde 7.5 milyar olan dünya nüfusunun 2030 'da 8.5 milyara, 2050 'de ise 10.1 milyara ulaşacağ1 tahmin edilmektedir (United Nations, 2019). Hızla artan nüfusa paralel olarak enerji kaynaklarından; petrol, kömür ve doğal gaz gibi fosil yakitların daha fazla kullanımı sonucu atmosfere salınan ve sera etkisi oluşturan gazlar ve bu gazların atmosfer tarafindan geri emilememesi nedeniyle iklim küresel olarak hızla değişmeye başlamıştır (Akyüz, 2019). Bu değişim öncelikle artan sicaklık ve karbondioksit $\left(\mathrm{CO}_{2}\right)$ miktarlarında görülmüştür. NASA'nın resmi internet sitesinde yayınladığı son yer yüzeyiokyanus sıcaklık değişimi verilerine göre; 2000 yllından bu yana en sıcak 19 yil yaşanmıştır. 2016 'da yaşanan $1.02^{\circ} \mathrm{C}$ 'lik sapma değerinin aynısı 2020 yll için de rapor edilmiştir. NASA'nın bildirdiği bir diğer küresel iklim değişikliği göstergesi ise ormanlık ve tarım alanların yok edilmesi; fosil yakıtların yakılması gibi insan faaliyetlerinin yanı sıra solunum ve volkanik püskürmeler gibi doğal süreçlerle de açığa çıkan önemli bir sera gazı (1s1 tutma özelliğine sahip) olan $\mathrm{CO}_{2}$ 'dir. $\mathrm{CO}_{2}$ gazının atmosferdeki değeri bu verilere göre 2005 y1lında $378.5 \mathrm{mg} / \mathrm{kg}$ iken bu değer hizla artarak 2020 yılında $415 \mathrm{mg} / \mathrm{kg}$ değerine yükselmiştir (NASA, 2021). Atmosferdeki bu değişiklikler olası iklim krizinin habercisidir.

Küresel iklim değişikliği ve olası iklim krizine karş1, 1988 yıllında, Birleşmiş Milletler (BM) ilk kez Hükümetlerarası İklim Değişikliği Paneli’ni (IPCC) düzenlemiştir ve o tarihten beri bu durumla mücadele etmektedir (Perçin, 2017). Bu panelin Ekim 2018'de yayınladığı rapora göre; küresel olarak $2^{\circ} \mathrm{C}^{\prime}$ lik bir artı̧s ile birlikte yeşil alanların çölleşmesi, ani iklim değişiklikleri ve mahsul verimini etkileyen yer seviyesindeki ozon, denizdeki besin güvenliğini etkileyen deniz yüzeyi sicakllğ1 ve mercan ağartmas1 gibi tehditlerin olas1 iklim krizini daha da hızlandıracağı bildirilmiştir
(Watts vd., 2020). Bunun üzerine BM'nin düzenli periyotlarla yayınladığı kalkınma amaçlanı Sürdürülebilir Kalkınma Amaçları adını alarak, 2030 Sürdürülebilir Kalkınma Gündemi'nin bir parçası olmuştur ve tüm BM üye devletleri tarafından imzalanmıştır. Yayınlanan kalkınma amaçları 17 maddeden oluşmakta olup; tüm dünyada yoksulluğa ve açlı̆̆a, cinsiyet eşitsizliğine son vermek, olası bir iklim krizi ile mücadele etmek gibi ekolojik, sosyal ve kültürel sorunların çözüme kavuşturulmasını hedeflemiştir (United Nations, 2016). Bu maddelerin en önemlilerinden biri "Açlı̆̆a Son" başlığ1 ile oluşturulan ikinci sürdürülebilir kalkınma amacıdır. Bu maddenin Sürdürülebilir Kalkınma Amaçları kapsamına alınmasında dünya genelinde besin kaynaklarının eşit olarak dağıtılamaması, tarım alanlarının verimsizleştirilmesi ve su krizi gibi etmenlerin etkisi vardır. BM'nin 2019 verilerine göre; 690 milyon insan açlıkla mücadele etmektedir ve tahminen 2 milyar insan ise güvenli, besleyici ve yeterli besine düzenli bir şekilde ulaşamamaktadır. Ayrıca 144 milyon çocuğun yaşına göre boy uzunluğunun kısa (bodur), 47 milyon çocuğun ise sınırlı besin alımı ve çeşitli enfeksiyonlar nedeniyle akut malnutrisyon ile karşı karşıya olduğu bildirilmiştir (United Nations, 2021). Buna göre dünya genelinde her yaş grubundaki bireyin güvenilir, besleyici ve sağlıklı beslenmeden eşit ölçüde yararlanabilmesi için yeni bir tanım ortaya çıkmıştır. Bu tanım, iklim krizi ile doğal kaynakların aşırı derecede tahrip olmasını ve tüketimini önlerken aynı zamanda uzun vadeli sağlığ1 korumak için beslenme kurallarına uyan beslenme modellerine atıfta bulunmak için öne sürülen "Sürdürülebilir Beslenme"dir (Spiker vd., 2020). Dünyada ortaya çıtı̆̆g günden beri güncelliğini yitirmemiş olan bu kavram ülkemizde ancak son yıllarda önem kazanmış durumdadır. $\mathrm{Bu}$ derlemenin amac1, sürdürülebilir beslenme ve çevresel etki açısından devamlıllğı en fazla olan bitkisel kaynaklı besinleri temel alan beslenme modelleri ile gelecek yüzyıllarda sera gazı etkisini azaltmak için tüketilebilecek alternatif protein 
kaynakları hakkında insanların bilinç düzeyini artırmak adına kapsamlı bilgi sunmaktır.

\section{METOT}

$\mathrm{Bu}$ amaçla, son on yılda yapilmış çalışmalar PUBMED, Google Scholar ve Dergipark veri tabanlar1 kullanılarak Aralık 2020 - Şubat 2021 tarihleri arasında taranmıştır. Veri tabanlarında kullanılan anahtar kelimeler şunlardır: "sustainability","sustainable nutrition", "greenhouse gas emissions", "Mediterranean diet", "Nordic diet", "double pyramid model", "vegetarian diet", "plant based protein", "alternative protein sources", "microalgae", "macroalgae", "insects", "cultured meat", "yeni besinler", "bitkisel protein", "diyet örüntüleri" ve "yenilebilir böcekler"dir. Toplam 214 araştırma ve derleme makalesi ile teze ulaşılmıştır. Derlemeye dahil edilme kriterleri; sürdürülebilirlik, sürdürülebilir beslenme modelleri ve alternatif protein kaynaklarını içermesidir. Toplam 39 araştırma makalesi ile 34 derleme makalesi ve 2 tez derlemeye dahil edilmiştir. Ayrıca konu ile ilgili 7 rapordan ve 5 web sitesinden yararlanılmıştır. Editöre mektuplar, kitaplar ve kongre özetleri derlemeye dahil edilmemiştir. Çizelge 1'de derlemeye dahil edilen çalışmalar için kullanılan yöntemler ve sonuçları detaylı olarak sunulmuştur.

Çizelge 1. Derlemeye dahil edilen çalışmalar için kullanılan yöntemler ve sonuçlar

\begin{tabular}{l}
\hline Derlemenin amacı aşağıdaki sorulardan oluşmaktaydı: \\
Sürdürülebilir beslenme nedir ve sürdürülebilir beslenmeye uygun beslenme modelleri nelerdir? \\
Geleneksel beslenme modellerinin diğer beslenme modellerine kıyasla SGE'ye etkileri nasıldır? \\
Sürdürülebilir beslenme için literatürde yer alan alternatif protein kaynaklarının besin içerikleri, sağlığın devamı \\
için yeterli midir? \\
Alternatif protein kaynakları ile yeni üretilen besinler ve bu besinlere karşı toplumun görüşü nelerdir? \\
\hline Toplam 214 Makale \\
(PUBMED: 148 , Google Scholar: 61 , Dergipark: 5$)$
\end{tabular}

Yöntem

\begin{tabular}{|c|c|}
\hline Veri toplama süreci & Aralık 2020 - Şubat 2021 \\
\hline Anahtar kelimeler & $\begin{array}{l}\text { "sustainability","sustainable nutrition", "greenhouse gas emissions", "Mediterranean } \\
\text { diet", "Nordic diet", "double pyramid model", "vegetarian diet", "plant based protein", } \\
\text { "alternative protein sources", "microalgae", "macroalgae", "insects" "cultured meat", } \\
\text { "yeni besinler", "bitkisel protein", "diyet örüntüleri" ve "yenilebilir böcekler" }\end{array}$ \\
\hline Uygunluk kriterleri & $\begin{array}{l}\text { Sürdürülebilirlik, sürdürülebilir beslenme modelleri ve alternatif protein kaynaklarını } \\
\text { içeren ilgili derlemeler, araştırma makaleleri, tezler, raporlar ve web siteleri }\end{array}$ \\
\hline Seçim süreci & $\begin{array}{l}\text { Taranan tüm çalışmaların derlemeye dahil edilme kriterlerini karşılayıp karşılama } \\
\text { durumları Şubat-Mart } 2021 \text { arası tüm yazarlar tarafından, Endnote programı kullanılarak } \\
\text { değerlendirilmiştir. }\end{array}$ \\
\hline \multirow[t]{7}{*}{ Bilgi kaynakları } & Sürdürülebilirlikle ilgili güncel bilgiler, veriler ve raporlar (21) \\
\hline & $\begin{array}{l}\text { Sürdürülebilir beslenme modelleri ve bu beslenme modelleri üzerine yapılan araştırma } \\
\text { makaleleri ile derlemeler ve bunların diğer beslenme modelleri ile karşılaştırılması (12) }\end{array}$ \\
\hline & Besin üretim sistemi faaliyetlerinin SGE üzerine etkisi ve besinlerin SGE miktarları (2) \\
\hline & Ülke bazında tüketilen diyetlerin SGE’ye etkileri üzerine yapılan çalışmalar (15) \\
\hline & Alternatif protein kaynakları ile ilgili güncel bilgiler ve veriler (14) \\
\hline & $\begin{array}{l}\text { Alternatif protein kaynaklarının protein içerikleri ve kaliteleri üzerine yapılan çalışmalar } \\
\text { ile içeriklerinin diğer besinlerle karşılaştırılması (8) }\end{array}$ \\
\hline & $\begin{array}{l}\text { Alternatif protein kaynaklarından üretilen yeni besinler ile kabul edilebilirliği ve bilinirliği } \\
\text { hakkındaki çalışmalar (15) }\end{array}$ \\
\hline $\begin{array}{l}\text { İlgili olmayan } \\
\text { kaynaklar }\end{array}$ & $\begin{array}{l}\text { Editöre mektuplar, kitaplar ve kongre özetleri, ülkelerin diyet modelleri ve SGE } \\
\text { miktarlarının karşılaştırıldığı geçmiş çalışmalar ve } 2019 \text { yılından daha eski raporlar (127) }\end{array}$ \\
\hline
\end{tabular}

SGE: Sera gazı emisyonu, *Parantez içerisinde yer alan rakamlar makale sayılarını vermektedir. 


\section{Sürdürülebilir Beslenme}

Sürdürülebilirlik, genellikle bir sistemin uzun vadede devam ettirilebilmesi ve gelecek nesillerin gereksinimlerini tehlikeye atmadan bugünün ihtiyaçlarını karşılayabilmesi olarak tanımlanır (United Nations, 2016). Bu tanıma göre toplum beslenmesinin sürdürülebilirliği için azalan kaynaklar ve artan çevre kirlilĭgi göz önüne alınarak çevreye olumsuz etkisi daha fazla olan besin kaynaklarının yerine alternatif kaynaklar tercih edilmelidir. Buna ek olarak, yine çevreyi olumsuz etkileyen geleneksel beslenme modelleri çevreye ve bireye olumlu katkıları olan farklı beslenme modelleri ile değiştirilmelidir. $\mathrm{Bu}$ beslenme modellerinin sürdürülebilir beslenmeye uygunluğu; beslenme modelinin ekosistem ve biyoçeşitlilik ile uyum içinde, geleneksel olarak kabul gören, herkes için ulaşılabilir, ekonomik olarak karşılanabilir, besin ögeleri açısından yeterli, güvenilir ve sağlıklı olması ile değerlendirilmektedir (Pekcan, 2019; Spiker vd., 2020). Sürdürülebilir beslenmeye uygun beslenme modelleri, düşük su ve karbon ayak izine sahip besinlerin tüketimini ele alarak besleyici yönden zengin geleneksel yiyeceklerin birçok türü de dahil olmak üzere besin çeşitliliğinin kullanımını teşvik etmelidir (Ruini vd., 2015). Ayrica bir beslenme şeklinin sürdürülebilirliği "besin üretim sistemi" içinde değerlendirilmelidir.

Besin üretim sistemi kavram1, günümüzde gıda endüstrisindeki süreçleri ve bileşenleri tanımlamak için kavramsal ve analitik bir araç olarak giderek artan bir kullanıma sahiptir. Bir besin üretim sistemi, tümü belirli süreçlerden etkilenen besin üretim sistemi faaliyetlerinden (yetiştirme, hasat etme, işleme, paketleme, taşıma, pazarlama, tüketme ve atık) ve diğer sistem bileşenlerinden oluşmaktadır (Zurek vd., 2018). Bu kapsamda, çevreye en az etkisi olan, insan sağlığına faydalı beslenme modelleri uzun y1llar boyunca varlıklanını sürdürebilecektir. Tüm dünyada olduğu gibi ülkemizde de olası iklim ve su krizi için kaynakları dengeli bir şekilde kullanan, mümkün olduğunca düşük sera gazı emisyonuna (SGE) neden olan, insan sağlığının devamlılığına yardımcı beslenme modellerinin yaygınlaştırılması önemlidir. Bu nedenle öncelikle besin üretim sistemi faaliyetlerinin çevreye etkileri detaylı bir şekilde analiz edilmeli ve gerekli önlemler alınmalıdır. Alınması gereken önlemlerin başında ise SGE miktarını azaltıcı faaliyetler gelmelidir.

\section{Besin Üretim Sistemi Faaliyetleri ve Sera Gazına Etkileri}

Besin üretim sistemi faaliyetlerinden tarım; ekilebilir arazinin üçte birini, küresel su kaynaklarının neredeyse dörtte üçünü ve enerjinin beşte birini kullanmaktadır. Buna ek olarak üretilen sebze ve meyveler doğrudan SGE'ye neden olmaktadir (Meyer ve Reguant-Closa, 2017).

SGE, küresel 1sınma potansiyeli olarak da bilinen karbondioksit eşdeğerleri ( $\mathrm{CO}_{2}$ eşd.) cinsinden ölçülür. Küresel ısınma potansiyelinde birinci sırada en önemli antropojenik sera gazı olarak $\mathrm{CO}_{2}$ yer alır. Azot oksit $\left(\mathrm{N}_{2} \mathrm{O}\right)$ ve metan $\left(\mathrm{CH}_{4}\right)$, $\mathrm{CO}_{2}$ gazindan sirasiyla 300 ve 25 kat daha fazla küresel 1sınma potansiyeline sahip diğer iki önemli sera gazlarıdır (Meyer ve Reguant-Closa, 2017).

Doğrudan emisyonlar ile üretim öncesi, üretim ve üretim sonrası oluşan sera gazı toplam SGE miktarının \%30'unu oluşturmaktadır (Meyer ve Reguant-Closa, 2017). Türkiye İstatistik Kurumu'nun (TÜİK) 2020 ylında yayınladığ1 son rapora göre; 2018 y1lı emisyonlarında $\mathrm{CO}_{2}$ eşd. olarak en büyük pay1 sırasiyla \%71.6 ile enerji kaynaklı emisyonlar, \%12.5 ile endüstriyel işlemler ve ürün kullanımı, \%12.5 ile tarımsal faaliyetler ve $\% 3.4$ ile atıklar oluşturmaktadır. $\mathrm{CH}_{4}$ emisyonlarının ise yarısından fazlası (\%63.1) tarımsal faaliyetlerden kaynaklanmaktadır (TÜİK, 2020).

Çeşitli besinlerin yetiştirilmesi ve üretilmesi esnasında ortaya çıkan SGE miktarları Çizelge 2'de gösterilmiştir. Bu çizelgeye göre; hayvansal protein kaynaklı besinlerin (sığır, kuzu, domuz, hindi eti, balık, bazı peynir türleri ve tofu vb.) üretimi ve işlenmesi oldukça fazla miktarda SGE'ye neden olmaktadır. Buna karşın bazı bitkisel protein kaynaklı besinler ve tahıl ürünleri (makarna, erişte, ekmek, yulaf, sebzeler, meyveler, fasulye, mercimek, yer fistığı, soya sütü vb.) düşük miktarda SGE ile ilișkilendirilmektedir. Buna göre; bireylerin besin seçiminde et ve et 
ürünlerinin azaltılması, doğrudan SGE miktarının düşürülmesine yardımcı olacaktır. Kırmızı etin az, bitkisel protein kaynaklı besinlerin ise daha fazla tüketildiği beslenme modellerinin (Akdeniz tipi, Nordik tipi, vejetaryen ve vegan beslenme modelleri gibi) yaygınlaşması ile SGE miktarının azalacağ1 tahmin edilmektedir. Bu sebeple düşük miktarlarda SGE'ye sahip, sürdürülebilir beslenme modellerinin tüketiminin toplum genelinde arttırlması önem arz etmektedir (Widmer vd., 2015; Dinu vd., 2017).

Cizelge 2. Besinlerin sera gazı emisyonlar1 (Meyer ve Reguant-Closa, 2017; Lovedav, 2019)

\begin{tabular}{|c|c|c|}
\hline Düşük SGE & Orta SGE & Yüksek SGE \\
\hline $\begin{array}{l}<1.0 \mathrm{~kg} \mathrm{CO}_{2} \text { eşd. } / \mathrm{kg} \text { yenilebilir } \\
\text { ağırlık }\end{array}$ & $\begin{array}{l}\text { 1.0-1.4 } \mathrm{kg} \mathrm{CO}_{2} \text { eşd. } / \mathrm{kg} \text { yenilebilir } \\
\text { ağırlık }\end{array}$ & $\begin{array}{l}>4.0 \mathrm{~kg} \quad \mathrm{CO}_{2} \quad \text { eşd. } / \mathrm{kg} \\
\text { yenilebilir ağırlık }\end{array}$ \\
\hline Patates & Tavuk & Sığır eti \\
\hline Makarna, erişte & Süt, tereyağ1, yoğurt & Kuzu \\
\hline Ekmek & Yumurta & Domuz \\
\hline Yulaf & Pirinç & Hindi \\
\hline Sebzeler (soğan, bezelye, havuç, & Kahvaltılik tahillar & Balık \\
\hline
\end{tabular}
misir vb.)

Meyveler (elma, armut, Ekmek üstüne sürülen soslar Peynir türleri ve tofu narenciye, erik, üzüm vb.)

Fasulye, mercimek

Findık, tohumlar

Şekerleme

Atıştırmalıklar

Soya sütü

Yer fisttğ1
Bisküvi, kek ve tatlllar

Meyveler (çilek, muz, kavun vb.)

Salata sebzeleri

Sebzeler (mantar, yeşil fasulye, karnabahar, brokoli, kabak vb.)

$\mathrm{CO}_{2}$ : karbondioksit, $\mathrm{CO}_{2}$ eşd.: karbondioksit eşdeğeri, kg: kilogram, km: kilometre, SGE: sera gazı emisyonu, 20 $50 \mathrm{~kg} \mathrm{CO} 2$ eşd. $/ \mathrm{kg}$ yenilebilir ağırlık kadar yüksek olabilir. Araba sürmek için ortalama $\mathrm{CO}_{2}$ emisyonu $0.186 \mathrm{~kg} \mathrm{CO}_{2}$ eşd./km'dir.

Üretim öncesi ve sonrası aşamalar dahil edildiğinde, \%21-37 oranında küresel SGE miktarına katkıda bulunan besin sistemlerini bireysel beslenme modeli seçimleri (özellikle tüketilen protein kaynakları) oldukça fazla etkilemektedir. $\mathrm{Bu}$ nedenle, bireysel düzeyde sürdürülebilir sağlıklı beslenme tercihlerinin gıda endüstrisindeki SGE miktarlarını azaltması beklenmektedir (Sugimoto vd., 2020). Ayrica Çizelge 2'de gösterildiği gibi hayvansal protein kaynaklı besinlerin yetiştirilmesi, üretilmesi ve işlenmesinin orta ve yüksek miktarda SGE'ye sebep olması dünya için bir uyarı niteliğindedir. Gelecek nesillerin ihtiyaçlarının karşılanabilmesi için şimdiden sürdürülebilir beslenme ve uygulamalan, yeni beslenme modelleri ve protein kaynakları gibi uygulamalar üzerinde çalsşllarak, bu konularda toplumun bilinç düzeyini artıran çeşitli politikalar geliştirilebilir.

\section{Sürdürülebilir Beslenme Uygulamaları Uygulanabilir Beslenme Modelleri}

Sürdürülebilir beslenmeyi sağlamak ve küresel sağlığ1 korumak için dünya kaynakları dikkatli bir şekilde kullanılmalı ve çevresel tahribatlardan kaçınılmalıdır. Bu sebeple literatürdeki çalışmalar; tarım teknolojisindeki gelişmelere; tedarik zinciri boyunca besin kayıplarına ve israfları azaltmaya; bireylerin, toplumların besin seçimlerini ve beslenme modellerini araştırmaya ve değiştirmeye odaklanmıştır (Fresán ve Sabaté, 2019; Loveday, 2019).

Öncelikle mevcut popülasyonun tercih ettiği beslenme modelleri, çevresel etki açısından 
incelenmelidir. $\mathrm{Bu}$ amaçla yapılan çalışmalarda farklı araştırma yöntemleri ve hesaplamalar kullanılmıstır (Çizelge 3). Örneğin; ABD'de yapılan bir çalışmada hane halkı kırmızı et harcamaları açısından 5 gruba ayrılmışır ve ortalama haftalık en düşük SGE miktarı, en az kırmızı et için harcama yapan grupta bulunmuştur (Boehm vd., 2019). İsviçre'de yapılan bir çalışmada, tüm İsviçre beslenme modelleri (vejetaryenler ve veganlar dahil), gida, ulaşım ve 1sıtma dahil olmak üzere tüm tüketim kategorileri için istenen bir hedef olan, kişi başına önerilen 0.6 ton $\mathrm{CO}_{2}$ eşd. SGE miktarı ile sürdürülebilirlik hedefinin oldukça üzerinde olduğu saptanmıştır (Sjörs vd., 2017). İtalya'da yapılan bir çalışmada ise mevcut beslenme modeline göre SGE miktarının erkeklerde $\% 48$ ve kadınlarda $\% 50$ azalmaya yol açacak, ulaşılabilir bir sağlıklı beslenme modelinin geliştirilebileceği gösterilmiştir (Grosso vd., 2020). Hindistan'da yapılan bir çalışmada "pirinç ve et" ağırlık beslenenlerde çevresel etkinin en fazla olduğu rapor edilmiştir (Green vd., 2018). Birleşik Krallık'ta yapılan bir çalışmada beslenme modeli ile ilişkili SGE miktarı, yüksek beslenme modeli kalitesi ve hipertansiyonu önlemek için beslenme yaklaşımları (DASH) skoru ile ters orantılı bulunmuştur. Sadece alt grup (<tahmini alım/önerilen alım: 0.70) analiz edildiğinde benzer sonuçlar görülürken; orta grupta (>tahmini alım/önerilen alım: 0.70) SGE miktarı tüm beslenme modeli kalitesi ölçümleri ile ters ilişki göstermiştir (Murakami ve Livingstone, 2018). İlginç olarak Danimarka'da yapılan bir çalışmada sebzeden zengin beslenme, en düşük sığır eti alımına ve toplamda en düşük kırmızı et alımına sahip olmasina rağmen, geleneksel ve fast-food beslenme modelleriyle neredeyse aynu karbon ayak izine sahip olarak bulunmuştur (Mogensen vd., 2020). Ayrıca bu çalısmalardan farklı olarak, Peru'da yapılan bir çalışmada SGE miktarı ile sosyal harcama veya akademik durum arasinda güçlü ve pozitif bir korelasyon saptanmıştır (Vázquez-Rowe vd., 2017). Bu sonuçlar bilinç düzeyi artışının SGE miktarı üzerindeki önemli etkisini göstermektedir.

Cizelge 3. Ceșitli beslenme modelleri ve sera gazı emisyonları

\begin{tabular}{|c|c|c|c|c|c|}
\hline Ülke & Kullanılan yöntem & Beslenme modeli & $\begin{array}{lll}\text { SGE } & (\mathrm{kg} & \mathrm{CO}_{2} \\
\text { eşd./kg/gün) } & \end{array}$ & Sonuçlar & Kaynak \\
\hline Avustralya & $\begin{array}{l}\text { Ulusal Sağlık } \\
\text { Araştırması verileri }\end{array}$ & $\begin{array}{l}\text { Ulusal beslenme } \\
\text { rehberine göre } \\
\text { uygulanan } \\
\text { beslenme modelleri }\end{array}$ & $\begin{array}{lr}\text { SGE } & \text { miktarları } \\
\text { sırasıyla; } & \text { erkekler ve } \\
\text { kadınlar } & \text { için } 18.72 \\
\text { (2377 } & \text { kkal/gün); } \\
13.73 & \text { (1772 } \\
\text { kkal/gün) } & \end{array}$ & $\begin{array}{lr}\text { Düşük kaliteli yüksek } \\
\text { SGE } & \text { beslenme } \\
\text { modelinde } & 25.2 ; \\
\text { önerilen } & \text { beslenme } \\
\text { modelinde } & 20.4 ; \\
\text { mevcut } & \text { beslenme } \\
\text { modelinde } 19.7 \text {; yüksek } \\
\text { kaliteli düşük SGE } \\
\text { beslenme modelinde } \\
13.9 \mathrm{CO}_{2} \text { eşd. } \\
\end{array}$ & $\begin{array}{l}\text { Hendrie vd., } \\
2016\end{array}$ \\
\hline $\begin{array}{l}\text { Çin, Japonya } \\
\text { Vietnam, Güney } \\
\text { Kore, Tayvan, } \\
\text { Singapur ve } \\
\text { Hong Kong }\end{array}$ & $\begin{array}{l}\text { Besin tüketim anketi ve } \\
\text { Ulusal veriler }\end{array}$ & 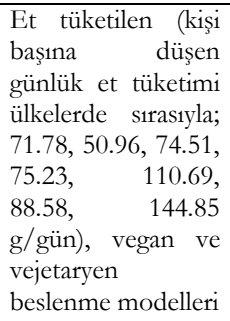 & 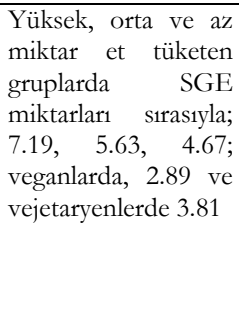 & $\begin{array}{l}\text { Vejetaryen } \\
\text { beslenenlerde } 48.83 \\
\text { milyon metrik ton } \mathrm{CO}_{2} \\
\text { eşd. SGE'de azalma } \\
\text { (2012, Fransa ve } \\
\text { Birleşik Krallik'taki } \\
\text { toplam SGE'lerin } \\
\text { sirasıyla \%11.3 ve } \\
\% 8.9 \text { 'una eşit) }\end{array}$ & Tseng, 2020 \\
\hline Türkiye & $\begin{array}{l}\text { Ulusal rehberden elde } \\
\text { edilen veriler }\end{array}$ & $\begin{array}{l}\text { Mevcut beslenme } \\
\text { modeli }\end{array}$ & $\begin{array}{l}\text { SGE miktarları } \\
(2000 \mathrm{kkal} / \text { gün için) } \\
1.14-3.28\end{array}$ & $\begin{array}{l}\text { Toplam SGE, besin } \\
\text { kayb1 ve atık dahil } \\
\text { olmak üzere kişi başına } \\
3.3 \mathrm{~kg} \mathrm{CO} \mathrm{CO}_{2} \text { eşd./gün }\end{array}$ & Acet, 2017 \\
\hline Arjantin & $\begin{array}{l}\text { Ulusal rehberden elde } \\
\text { edilen veriler }\end{array}$ & $\begin{array}{l}\text { Mevcut, önerilen, } \\
\text { büyükbaş } \\
\text { hayvanların etini } \\
\text { tüketmeyen, lakto- } \\
\text { ovo vejetaryen, } \\
\text { vegan beslenme } \\
\text { modelleri }\end{array}$ & $\begin{array}{lr}\text { SGE } & \text { miktarları } \\
\text { sirasılyla } & (2000 \\
\text { kkal/gün } & \text { için }) ; 5.4, \\
3.9,2.1,1.73,1.47\end{array}$ & $\begin{array}{l}\text { Et içeren beslenme } \\
\text { modellerinin lakto-ovo } \\
\text { vejetaryen ve vegan } \\
\text { beslenme modellerine } \\
\text { göre besin } \\
\text { verimliliklerinde } \\
\text { azalma }\end{array}$ & $\begin{array}{l}\text { Arrieta ve } \\
\text { González, } 2018\end{array}$ \\
\hline
\end{tabular}


Çizelge 3. devam

\begin{tabular}{|c|c|c|c|c|c|}
\hline Ülke & Kullanılan yöntem & Beslenme modeli & $\begin{array}{lll}\text { SGE } \quad(\mathrm{kg} & \mathrm{CO}_{2} \\
\text { eşd./kg/gün) } & \end{array}$ & Sonuçlar & Kaynak \\
\hline Hindistan & Besin tüketim sıklı̆ı & $\begin{array}{l}\text { Pirinç ve düşük } \\
\text { çeşitlilik, pirinç ve } \\
\text { meyve, buğday ve } \\
\text { bakliyat, buğday, } \\
\text { pirinç ve yağlar, } \\
\text { pirinç ve et, mevcut } \\
\text { beslenme modelleri }\end{array}$ & $\begin{array}{lrr}\text { SGE } & \text { miktarlar1 } & \text { ve } \\
\text { toplam } & \text { kkal/gün } \\
\text { sirasiyla; } & 2.47 & (2369 \\
\text { kkal), } & 2.57 & (2762 \\
\text { kkal), } & 2.30 & (3027 \\
\text { kkal), } & 2.05 & (3344 \\
\text { kkal), } & 3.31 & (2723 \\
\text { kkal), } & 2.42 & (2883 \\
\text { kkal) } & & \\
\end{array}$ & $\begin{array}{l}\text { Pirinç ve et tüketen } \\
\text { grupta çevresel etki en } \\
\text { fazla }\end{array}$ & Green vd., 2018 \\
\hline Birleşik Krallık & $\begin{array}{l}\text { Ulusal rehberden elde } \\
\text { edilen }\end{array}$ & $\begin{array}{l}\text { Toplam, orta ve alt } \\
\text { grup (Tahmini } \\
\text { alım/önerilen alım: } \\
0.70 \text {, bu değerin alt1 } \\
\text { alt, üstü orta grup) }\end{array}$ & $\begin{array}{l}\text { SGE miktarları ve } \\
\text { toplam kkal/gün } \\
\text { sirasiyla; } 5.7 \quad(2552 \\
\mathrm{kkal} / \text { gün }), 6.3 \text { (2337 } \\
\mathrm{kkal} / \text { gün), } 5.0 \text { (2800 } \\
\mathrm{kkal} / \text { gün) }\end{array}$ & $\begin{array}{lr}\text { Yüksek } & \text { beslenme } \\
\text { modeli kalitesi ve } \\
\text { DASH skoru ile SGE } \\
\text { ters ilisskili; orta grupta } \\
\text { SGE tüm beslenme } \\
\text { modeliräralitesi } \\
\text { ölçümleri ile ters ilişkili }\end{array}$ & $\begin{array}{l}\text { Murakami } \\
\text { Livingstone, } \\
2018\end{array}$ \\
\hline Lübnan & $\begin{array}{l}\text { Besin tüketim s1klı̆g } \\
\text { anketi }\end{array}$ & $\begin{array}{lr}\text { Batı tarzı, Lübnan- } \\
\text { Akdeniz } \\
\text { yüksek proteini, } \\
\text { mevcut beslenme } \\
\text { modelleri }\end{array}$ & $\begin{array}{lr}\text { SGE miktarlar1 } & \text { (1000 } \\
\text { sirasiyla } & (100 \text { kal/gün için); } 1.58, \\
\text { kkal } & 0.90,1.40,4.06\end{array}$ & $\begin{array}{l}\text { Batı ve yüksek proteinli } \\
\text { beslenme modellerinde } \\
\text { yüksek çevresel ayak } \\
\text { izi; Lübnan-Akdeniz } \\
\text { tipi beslenme } \\
\text { modelinde düşuk su } \\
\text { kullanımı ve SGE } \\
\text { miktarı }\end{array}$ & Naja vd., 2018 \\
\hline $\begin{array}{l}\text { Amerika Birleşik } \\
\text { Devletleri }\end{array}$ & $\begin{array}{l}\text { Ulusal rehberden elde } \\
\text { edilen veriler }\end{array}$ & $\begin{array}{l}\text { Haftalık kırmız1 et } \\
\text { harcamalarına göre: } \\
\text { Q1-1.65\$, Q2- } \\
\text { 10.61\$, Q3-20.46\$, } \\
\text { Q4-26.19\$, Q5- } \\
39.05 \$\end{array}$ & \begin{tabular}{llr} 
SGE & \multicolumn{2}{l}{ miktarlar1 ve } \\
toplam & kkal/gün \\
sirasiyla; 120 & $(24653$ \\
kkal), & 150 & $(39643$ \\
kkal), & 160 & $(47141$ \\
kkal), & 142 & $(43608$ \\
kkal), & 140 & $(40447$ \\
kkal) & & \\
\end{tabular} & $\begin{array}{l}\text { Ortalama haftalı SGE, } \\
\text { Q2-Q5'teki hanelere } \\
\text { k1yasla Q1'deki haneler } \\
\text { için en düşük }\end{array}$ & Boehm vd., 2019 \\
\hline Hollanda & $\begin{array}{l}\text { Hollanda Ulusal besin } \\
\text { tüketim anketi }\end{array}$ & $\begin{array}{l}\text { Mevcut beslenme } \\
\text { modeli }\end{array}$ & $4.21(2420 \mathrm{kkal} /$ gün $)$ & $\begin{array}{l}\text { Gelecekte SGE } \\
\text { hedeflerine uyan } \\
\text { beslenme modellerinin } \\
\text { daha az et (özellikle } \\
\text { sığır eti) ve daha fazla } \\
\text { bitkisel besin içermeli }\end{array}$ & $\begin{array}{l}\text { Broekema vd., } \\
2020\end{array}$ \\
\hline İsviçre & $\begin{array}{l}\text { Ulusal rehberden elde } \\
\text { edilen veriler }\end{array}$ & $\begin{array}{l}\text { Mevcut, vejetaryen, } \\
\text { vegan, zayıflama, } \\
\text { glutensiz beslenme } \\
\text { modelleri ile } \\
\text { kadınlar, erkekler, } \\
\text { ilköğretim, orta } \\
\text { öğretim ve yüksek } \\
\text { öğretim beslenme } \\
\text { durumları }\end{array}$ & 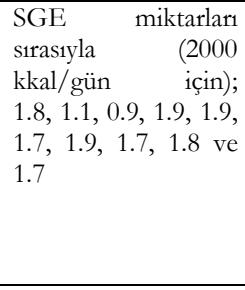 & $\begin{array}{l}\text { Tüm beslenme } \\
\text { modelleri (vejetaryenler } \\
\text { ve veganlar dahil), gida, } \\
\text { ulaşım ve isıtma dahil } \\
\text { olmak üzere tüm } \\
\text { tüketim kategorileri için } \\
\text { kişi başına düşen } 0.6 \\
\text { ton } \mathrm{CO}_{2} \text { eşd. SGE }\end{array}$ & $\begin{array}{l}\text { Ernstoff vd., } \\
2020\end{array}$ \\
\hline İtalya & $\begin{array}{l}\text { Ulusal rehberden elde } \\
\text { edilen veriler }\end{array}$ & $\begin{array}{l}\text { Mevcut beslenme } \\
\text { modeli }\end{array}$ & $\begin{array}{ll}\text { SGE miktarlar1 ve } \\
\text { toplam kkal/gün } \\
\text { sirasiyla; erkekler ve } \\
\text { kadınlar için } 4.0 \\
(2406 \text { kkal); } 3.2 \\
(1947 \text { kkal) }\end{array}$ & $\begin{array}{lr}\text { SGE'nin } & \text { erkeklerde } \\
\% 48 \text { ve kadınlarda \%50 } \\
\text { azalmaya yol } & \text { açacak, } \\
\text { ulaşlabilir bir } & \text { sağlikli } \\
\text { beslenme } & \text { modeli } \\
\text { geliştirilmeli } & \\
\end{array}$ & Grosso vd., 2020 \\
\hline Danimarka & $\begin{array}{lr}\text { Ulusal } & \text { Beslenme } \\
\text { Alşsanlikları } & \text { ve } \\
\text { Fiziksel } & \text { Aktivite } \\
\text { Araştırması'ndan } & \text { elde } \\
\text { edilen veriler } & \end{array}$ & $\begin{array}{l}\text { Mevcut, geleneksel, } \\
\text { fast-food, sebzeden } \\
\text { zengin, yüksek et } \\
\text { tüketilen beslenme } \\
\text { modelleri }\end{array}$ & $\begin{array}{l}\text { SGE miktarları ve et } \\
\text { tüketimleri sirasiyla } \\
\text { (2400 kkal/gün için); } \\
4.4(513 \mathrm{~g}), 4.2 \text { (560 } \\
\text { g), } 4.3 \text { (409 g), } 5.0 \\
(1023 \mathrm{~g})\end{array}$ & $\begin{array}{l}\text { Sebzeden zengin } \\
\text { beslenme modeli, } \\
\text { geleneksel ve fast-food } \\
\text { beslenme modelleriyle } \\
\text { neredeyse ayn karbon } \\
\text { ayak izine sahip }\end{array}$ & $\begin{array}{l}\text { Mogensen vd., } \\
2020\end{array}$ \\
\hline
\end{tabular}

$\mathrm{CO}_{2}$ : karbondioksit, $\mathrm{CO}_{2}$ eşd: karbondioksit eşdeğeri, SGE: sera gazı emisyonu, DASH: Hipertansiyonu önlemek için diyet yaklaşımları, kkal: kilokalori, g: gram, \$: dolar 
Bazı bilimsel çalışmalarda, ülkelerin yıllar içinde değişen beslenme alışkanlıkları ile SGE miktarlarındaki değişimleri de gösterilebilmektedir. Örneğin; Avustralya'da 2014 yilında yapılan çalışmada, 1995 yılı Ulusal Sağlık Araştırma verileri kullanılmış ve tüketilen geleneksel beslenme modeli ile SGE miktarı kişi başı $14.5 \mathrm{~kg} \quad \mathrm{CO}_{2}$ eşd. olarak bulunmuştur (Hendrie vd., 2014). 2016 yllinda yapilan çalışmada ise 2011-2012 yilı Ulusal Sağlık Araştırması'nda belirtilen 3 beslenme modeli SGE ve diyet kaliteleri açısından değerlendirilmiştir. Oluşan SGE miktarları; düşük kaliteli, yüksek SGE miktarına sahip beslenme modelinde $25.2 \mathrm{~kg}$ $\mathrm{CO}_{2}$ eşd., yüksek kaliteli düşük SGE miktarına sahip beslenme modelinde ise $13.9 \mathrm{~kg} \mathrm{CO} 2$ eşd.'dir. Ulusal rehberde önerilen beslenme modelinde $20.4 \mathrm{~kg} \mathrm{CO} 2$ eşd.; mevcut ortalama beslenme modelinde ise $19.7 \mathrm{~kg} \mathrm{CO}$ eşd. olarak bulunmuştur (Hendrie vd., 2016). Yıllar içindeki değişimin incelenmesi, ülkede sürdürülebilir beslenme adına atılan adımları ve sera gazını azaltıcı diğer faaliyetlerin etkilerini görebilmek için oldukça önemlidir.

$\mathrm{Bu}$ tarz çalışmalarla ülkeler yillar boyunca gösterdikleri değişimleri raporlayabilme firsatına sahip olabilecektir. Ülkemizde ise bu konuda 2017 yilında yapılmış sadece bir çalışmaya rastlanmıştır. $\mathrm{Bu}$ çalışmada 2014 yılında yayınlanan Türkiye Beslenme ve Sağlık Araştırması'ndan elde edilen sonuçlar analiz edilmiştir ve günlük beslenme modelini oluşturan gerçek kaloriler için beslenme modeli senaryosuna (günlük $3706 \mathrm{kkal}$ ) dayalı olarak hesaplanan 2013 yllındaki besin tüketimiyle ilişkili toplam SGE miktarı, besin kaybı ve atıklar dahil olmak üzere kişi başına $3.3 \mathrm{~kg} \mathrm{CO} 2$ eşd./gün bulunmuştur (Acet, 2017). Diğer ülkelerde olduğu gibi belirli periyotlar ile tarımın ve beslenme modellerinin çevreye etkilerini araştıran çalışmalar tekrarlanarak ülkemizin mevcut durumu hakkında bilgi toplanabilir.

Yapılan çalışmalarda görüldüğü üzere, sürdürülebilirlik adına gerekli adımların atılması oldukça önemlidir. Sürdürülebilir beslenme tanımına uyan beslenme modellerinin başında vejetaryen ve vegan beslenme gelirken; Akdeniz ve Nordik tipi beslenme ile 2014 yllinda hazırlanan Çift Piramit Modeli de sürdürülebilir beslenme açısından gündemde olan önemli beslenme modelleridir. Bunun yanı sira hayvansal protein kaynaklı besinlerin yüksek miktarda SGE'ye yol açtıkları görülmektedir. Çevreye en az etkisi olan beslenme modellerinin dünya genelinde yaygınlaşmasına ek olarak sürdürülebilir beslenmeyi sağlayabilmek için besin ögesi içerikleri hayvansal protein kaynaklı besinlere yakın olan herkes tarafindan erişilebilir ve kabul görebilecek alternatif protein kaynaklarının üretimine yönelik çalışmalar ön plandadır.

\section{Vejetaryen Beslenme}

Vejetaryen beslenme şekilleri (et ve et ürünleri tüketilmeyen) içerdikleri yüksek lif, meyve ve sebze tüketimi ile (Kumar vd., 2017) bitkisel protein kaynaklı beslenme modellerinin başında gelir ve birçok hastalık riskinin azalması ile ilişkilidir. Vejetaryenlerde tip 2 diyabet, obezite, koroner kalp hastalıkları ve diğer bulaşıcı olmayan hastalıklara yakalanma riskinin daha düşük olduğu; ayrıca bu tip beslenme modelini uygulayan bireylerin daha uzun yaşam ömrüne sahip olduğu çeşitli çalışmalarda gösterilmiştir (Nelson vd., 2016; Dinu vd., 2017; Satija ve Hu, 2018).

Vejetaryen beslenmenin çeşitli türleri mevcuttur. Bunlar; lakto-ovo vejetaryenler, et tüketmeyen ancak süt ve süt ürünü ile yumurta tüketebilenler; pesketaryenler balık hariç diğer et çeşitlerini tüketmeyenler; ovo vejetaryenler sadece yumurta tüketenler; veganlar ise hiçbir hayvansal kaynaklı besin tüketmeyenler olarak sinıflandırılmaktadır (Fresán ve Sabaté, 2019).

$\mathrm{Bu}$ beslenme modelleri Çizelge 2'deki düşük miktar SGE grubunda yer alan çoğu besini temel almaktadır. Ayrıca üretim sırasındaki kaynak ihtiyaçları karşılaştırıldığında; sığır eti üretmek için sebze üretiminden 8-14 kat daha fazla kaynağa ihtiyaç duyulmaktadır. Örneğin; $1 \mathrm{~kg}$ fasulye üretimi için $3.8 \mathrm{~m}^{2}$ arazi, $2.5 \mathrm{~m}^{3} \mathrm{su}, 39 \mathrm{~g}$ gübre ve 2.2 g pestisit kullanılırken; aynı miktarda sığır eti üretimi için $52 \mathrm{~m}^{2}$ arazi, $20.2 \mathrm{~m}^{3} \mathrm{su}, 360 \mathrm{~g}$ gübre ve $17.2 \mathrm{~g}$ pestisit gerekmektedir (Sranacharoenpong vd., 2015). 
Türlerine göre çeşitli hayvansal protein kaynaklı besinlerin bireylerin beslenmelerinden çıkarılması ile bu beslenme modellerinin çevreye olan zararlı etkileri oldukça azalacaktır. Çizelge 3'te de gösterildiği gibi Arjantin'de mevcut beslenme modelinin SGE miktarı $2000 \mathrm{kkal} /$ gün için 5.4 $\mathrm{CO}_{2} \quad$ eşd./kg olarak ölçülürken; lakto-ovo vejetaryenlerde $1.73 \mathrm{CO}_{2}$ eşd. $/ \mathrm{kg}$; veganlarda ise $1.47 \mathrm{CO}_{2}$ eşd./kg olarak ölçülmüştür (Arrieta ve González, 2018). Vejetaryen veya vegan olarak beslenen Mahayana Budistleri üzerinde yapilmış bir çalışmada ise mevcut popülasyonda sadece Mahayana Budistlerinin bile bu şekilde beslenmeleri ile SGE miktarında 48.83 milyon metrik ton $\mathrm{CO}_{2}$ eşd. azalmanın görüleceği öngörülmektedir. Bu değerin 2012 yılında Fransa ve Birleşik Krallık'ta ölçülen toplam SGE miktarının sirasıyla \%11.3'üne ve \%8.9'una eşit olması vejetaryen beslenmenin çevreye etkileri göz önüne alındığında bir kez daha ne kadar önemli olduğunu göstermektedir (Tseng, 2020).

Literatürde sağllğa ve çevreye faydaları kanıtlanmış olmasına rağmen vejetaryen beslenmenin ülkemizdeki görülme sıklığ1 oldukça düşüktür. 15 yaş ve üzeri bireylerde vejetaryen beslenme sıklığı \%0.7 (erkek: \%0.2, kadın: \%1.2) iken vejetaryen beslenenlerin \%45.0'1 k1smi vejetaryen, \%33.4'ü lakto-ovo vejetaryen, $\% 11.7$ 'si ovo vejetaryen, \%7.1'i pesketaryen, \%2.8’i lakto vejetaryendir (T.C. Sağlık Bakanlı̆̆1, 2019). Sürdürülebilir beslenme adına atılacak adımların başında gelen sağlığa ve çevreye yararlı beslenme modellerinin yaygınlaşması için; toplumun bu beslenme modelleri ve olası sağlik faydaları hakkında daha fazla bilgilendirilmesi gerekmektedir.

\section{Akdeniz ve Nordik Tipi Beslenme}

Akdeniz tipi beslenme kavramı, kardiyovasküler sistem için sağlıklı bir beslenme modelinden sürdürülebilir beslenme modeline kadar son 50 yılda aşamalı bir gelişme göstermiştir (Widmer vd., 2015). 1990'ların başından itibaren, çevresel sürdürülebilirlikle ilgili artan endişeler dikkate alınarak, bitkisel besin merkezli bir beslenme modeli olan Akdeniz tipi beslenme, daha düşük çevresel etkilere sahip sürdürülebilir bir beslenme modeli olarak kabul edilmiştir (Dernini vd., 2017).
Akdeniz tipi beslenme modeli; yüksek miktarda sızma zeytinyağı, ağırlıklı olarak yeşil yapraklı sebzeler olmak üzere tüm sebzeler, meyveler, tahıllar, kabuklu yemişler, bakliyatlar ve baklagillerin tüketimini içerir. Ayrıca bu beslenme modelinde orta düzeyde balık ve diğer et ile et ürünlerini, süt ve süt ürünlerini, kırmızı şarap; düşük miktarda da yumurta ve şeker yer almaktadır (Davis vd., 2015). Akdeniz tipi beslenme, bu bileşenleri ile ortalamadan düşük SGE miktarı başta olmak üzere çevresel etkisi diğer beslenme modellerine göre daha az olan bir beslenme modelidir (Dernini vd., 2017). Lübnan'da yapılan bir çalışmada, yetişkinler arasında batı ve yüksek proteinli beslenme modellerinin fazla miktarda çevresel ayak izlerine sahip olduğu; Lübnan-Akdeniz beslenme modelinin ise daha düşük su kullanımı ve SGE miktarına sahip olduğu bulunmuştur (Naja vd., 2018).

Ayrica bu beslenme modeli temel alınarak oluşturulan; Danimarka, Finlandiya, İzlanda, Norveç ve İsveç'te yaygın olarak kabul görmüş Nordik tipi beslenme modelinde; sebze, bakliyat, meyve, balık ve diğer deniz ürünleri, kabuklu yemişler ve tohumlar artırılırken, şekerli içecek ve yiyecekler, tuz, işlenmiş kırmızı et ve alkol sinırlandırılır. Bunun yanı sira tam tahıllı besinler, bitkisel yağlar, az yağlı süt ürünleri, bitkisel yağ bazlı sürülebilir ürünler de bu beslenme modelinde tüketilebilmektedir (Meltzer vd., 2019).

İki beslenme modelinde de yüksek miktarda tüketimi önerilen besinler düşük ve orta düzey SGE miktarına neden olmaktadır. Bu amaçla Hollanda'da yapılan bir çalışmada, geleneksel olarak tüketilen sığır eti, peynir, tereyağı ve atıştırmalıklardan; bitkisel besinlere, balık ve kabuklu deniz ürünlerine doğru geçişin gerekli olduğu gösterilmiştir (Broekema vd., 2020). Geleneksel beslenme modelleriyle karşılaştırıldığında hayvansal kaynaklı besinlerin oldukça az tüketimi, Akdeniz ve Nordik tipi beslenmeyi sürdürülebilir beslenme açısından oldukça önemli bir noktaya getirmektedir. Vejetaryen ve Nordik tipi beslenme modellerine kıyasla Akdeniz tipi beslenme modelinin 
ülkemizde bilinirliği ve uygulanabilirliği daha yüksektir (Bayındır Gümüss ve Yardımcı, 2019; Duran vd., 2019) fakat tüm dünyada olduğu gibi ülkemizde de batı tarzı beslenme modeli gün geçtikçe artış göstermektedir (Bayram ve Öztürkcan, 2020b). Çevreye olan zararlı etkileri düşünüldüğünde, ülkemizde de halk1 bilinçlendirerek Akdeniz tipi beslenme modelini yaygınlaştırmak hem sürdürülebilirlik hem de sağlık üzerine olan olumlu etkileri açısından yararlı olabilir.

\section{Çift Piramit Modeli}

Sürdürülebilir beslenmeye uyarlanabilir beslenme modelleri araştırılırken; İtalya'da Barilla Gıda ve Beslenme Merkezi (BCFN), farklı besin gruplarının sağlıklı beslenmeye hangi ölçüde katkıda bulunduklarının ve çevresel etkilerinin resimli bir temsili olan "Çift Piramit Modeli"ni geliştirmiştir (BCFN, 2010). Bu model iki grafikten oluşmaktadır. İlk piramitte Akdeniz tipi beslenme önerileri yer alırken; ikinci piramitte besinler ve çevreye olan olası zararlı etkileri arasındaki ilişki gösterilmektedir (Ciati ve Ruin, 2014). Beslenme düzeninde; piramidin tabanındaki meyve, sebze, tahıl ve bakliyatların yüksek tüketimi önerilirken; en üstte yer alan şeker ve kırmızı etin beslenme modelinde daha az yer alması gerektiği bildirilmiştir. Sağdaki piramidin en tepesinde ise çevreye en fazla zarar veren besinler olarak kırmızı et, peynir ve balık yer alırken; tahıl, makarna, pirinç, süt, meyve ve sebzelerin çevresel etkisinin nispeten diğer besinlere göre daha düşük olduğu görülmektedir (Şekil 1). Bu piramit, beslenme modeli olarak Akdeniz tipi beslenmeyi önermektedir. Ayrıca hayvansal ve bitkisel protein kaynaklı besinlerin çevreye etkilerinin illüstrasyon ile gösterilmesiyle sürdürülebilir beslenmeye örnek olabilecek beslenme modelleri için iyi bir kaynak niteliği taşımaktadır.

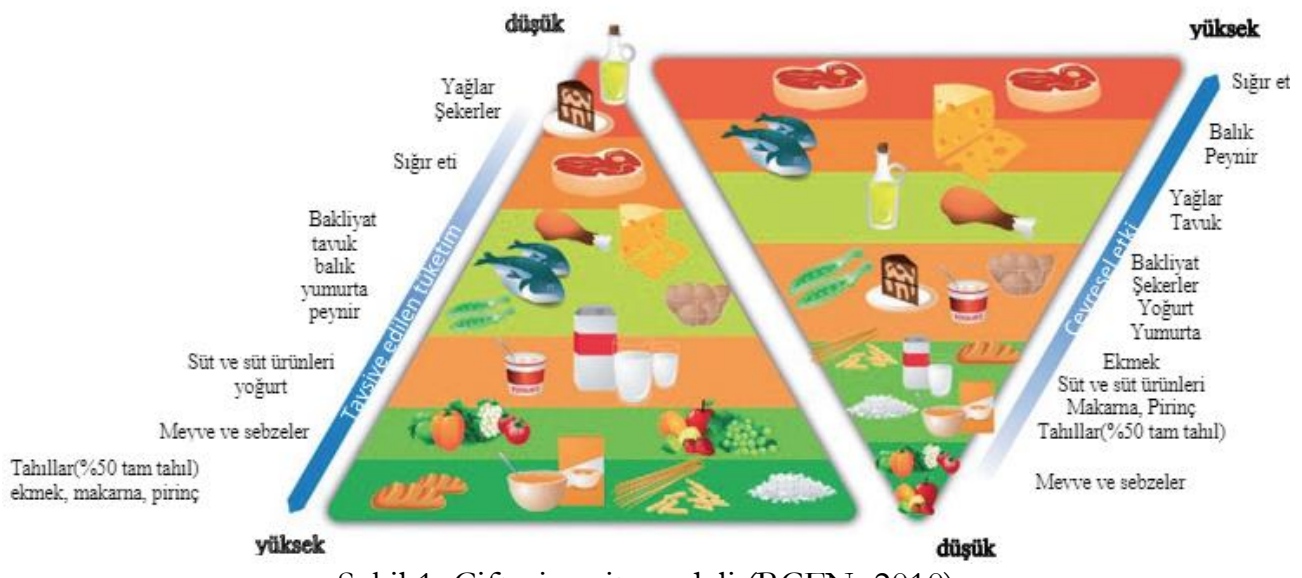

Şekil 1. Çift piramit modeli (BCFN, 2010)

Çizelge 3’te güncel literatürdeki geleneksel beslenme modelleri ile vejetaryen ve vegan beslenme, Akdeniz tipi beslenme gibi sürdürülebilir beslenmeye uygun beslenme modellerinin karşılaştırıldığı çalışmalar özetlenmiştir.

\section{Alternatif Protein Kaynaklar1}

Mevcut tüm esansiyel amino asit gereksinimlerini karşılayarak, kolayca sindirilip emilen; et, yumurta ve süt gibi geleneksel hayvansal protein kaynaklı besinler, yüksek kaliteli protein kaynakları olarak kabul edilir. Bununla birlikte, küresel nüfusun 2050 yılına kadar yaklaşık 10.1 milyara ulaşması; iklim değişikliği, biyolojik çeşitlilik kaybı, arazi kullanım değişikliği ve tatlı su kullanımı gibi çevresel zorluklarla birleștiğinde artan nüfusun protein ihtiyacını karşılamada çeşitli zorluklar görülecektir (Churchward-Venne vd., 2017). Bunun sonucunda; geleneksel hayvansal protein kaynaklı besinlerin yerine alternatif protein kaynaklarının üretiminin uygulanabilirliğine ilgi son yıllarda artmıştır (Aiking ve de Boer, 2020). 
Ayrıca besin üretimi sürecinde, hayvansal protein kaynaklı besinlerin üretimi çevre üzerinde bitki bazlı protein kaynaklarının üretiminden daha büyük bir olumsuz etkiye sahiptir (Tilman ve Clark, 2014; Aiking ve de Boer, 2020). Bunun başlica sebepleri hayvansal protein kaynaklarının daha fazla miktarda SGE'ye yol açması, daha fazla arazi ve nitrojen gereksinimi ile karasal ve suda yaşayan diğer biyoçeşitlilikler üzerindeki olası etkileridir (Davis vd., 2016; Grasso vd., 2019). İklim değişikliğini ve artan protein gereksinimini dengelemek için bilimsel çalışmalar ve gida endüstrisi, protein açısından zengin besin kaynakları geliştirmek için bileşen olarak alternatif protein kaynaklarını araştırmaktadır (GarcíaSegovia vd., 2020). Ancak bu araştırılan protein kaynaklarından hepsi ticarileştirilememektedir. Bir protein kaynağının stoklanıp, üretim faaliyetlerine sokulması için bazı özelliklere sahip olması gerekmektedir. Bu özellikler sirasıyla; makul bir maliyetle fazla miktarlarda depolanabilmesi, mevsimsel değişimlerinin minimal seviyede olması, ortam sicaklığında en az 12 ay kimyasal ve mikrobiyal olarak stabil kalabilmesi ve yasal olarak üretilebilmesidir. $\mathrm{Bu}$ özelliklere sahip olan alternatif protein kaynaklarından; bitkisel protein kaynağ1 algler, böcekten türetilmiş proteinler ve laboratuvar ortamında yetiştirilmiş et ile ilgili araştırmalar literatürde en yaygın olanlarıdır (Loveday, 2019).

\section{Bitkisel Protein Kaynakları}

BM, Sürdürülebilir Kalkınma Amaçları doğrultusunda her türlü açlık ve yetersiz beslenmeyi sona erdirmek için daha uygun fiyatlı ve besleyici protein kaynakları araştırmaktadır. Gelişmekte olan ülkelerde; kırmızı et, kümes hayvanları, balık, deniz ürünleri ve diğer yenilebilir tür etlerin yüksek fiyatları nedeniyle protein kaynakları genellikle tahıllar ve bakliyatlarla sınırlı kalmaktadır (Sahruzaini vd., 2020).

Tahılların yaklaşık \%75'ini karbonhidratlar oluştururken, protein içerikleri \%6-15 arasında değişmektedir. Protein kalitesi açısından tahıllar ve baklagiller karşılaştırıldığında tahılların protein sindirilebilirliği - düzeltilmiş amino asit skorlarının (PDCAAS) 63 ile 95 arasinda, kuru baklagillerin ise 68-100 arasında olduğu bildirilmiştir
(Köseoğlu, 2019). Lipit içerikleri tahıl çeşidine bağl1 olarak değişmekte; arpa, pirinç, çavdar ve buğdayda \%1-3, misırda \%5-9, yulafta $\% 5-10$ arasindadır (McKevith, 2004). Bakliyatlar ise içerdiği protein oranının daha yüksek olması nedeniyle diğer bitkisel besinlere kiyasla daha fazla tercih edilmektedir. Sistein ve metiyonin aminoasitlerini içermemesine rağmen protein içerikleri tahıllarda bulunan miktarın yaklaşık 2 katıdır (Parca vd., 2018). Bu protein içeriklerine göre ülkemizde yaygin olarak kullanılan tahılların ve bakliyatların besin ögesi içerikleri Çizelge 4'te sunulmuştur.

Her ne kadar protein içerikleri hayvansal protein kaynaklı besinler ile karşılaştırılabilecek düzeyde olsa da tarım topraklarının çölleşmesi, su ve iklim değişikliğinin tahılların ve bakliyatların üretimlerini önümüzdeki yıllarda zorlaştırabileceği düşünülmektedir. $\mathrm{Bu}$ nedenle üretimi nispeten iklime ve suya daha az bağımlı olan mikro ve makroalgler gibi yeni bitkisel protein kaynakları ön plana çımışır (Ścieszka ve Klewicka, 2019).

\section{Makro ve Mikroalgler}

Algler, tatlı su ve deniz sistemlerinde bulunan prokaryotik veya ökaryotik mikroskobik tek hücreli organizmalardır. Atmosferik oksijenin yaklaşık yarısını üretirler ve foto ototrofik olarak büyümek için $\mathrm{CO}_{2}$ 'yi kullanırlar. Yüzylllardır besin olarak tüketilmelerine rağmen alg proteininin ekstraksiyonu ve saflaştırılması ile ilgili araştırmalar yeni yeni yapılmaya başlamıştır (Loveday, 2019; Ścieszka ve Klewicka, 2019).

Yeryüzünde en bol bulunan alg sinifları Cyanophyceae (mavi-yeşil algler), Chlorophyceae (yeşil algler), Bacillariophyceae (diatomlar) ve Chrysophyceaeler (altın algler) olup kendi içlerinde makro ve mikroalgler başlıkları altında toplanmaktadırlar (García vd., 2017).

Arthrospira platensis (spirulina) ve Chlorella türleri gibi tek hücreli mikroalgler "Genel Olarak Güvenli" (Generally Recognized As Safe-GRAS) statüsündedir ve ticari olarak üretilebilmektedirler. Sırasıyla protein içerikleri $\% 21-70$ ve $\% 51-58$ dir. Makroalgler ise ticari olarak yetiştirilebilen; polisakkarit ve hayvan yemi 
kaynağ1 olarak kullanılabilen veya sebze olarak tüketilebilen çok hücreli deniz veya tatlı su bitkileridir (deniz yosunları). Protein içerikleri kırmızı deniz yosunlarının birçoğunda \%25-45 olup, kahverengi deniz yosunlarında ise bu değer \%15'ten daha azdir (Loveday, 2019). Ayrica yapilan in vitro çalışmalarda çoğu alg türlerinin protein kalitesinin \%35-88 arasinda değiştiği bildirilmiştir (Reitan, 2011; Bleakley ve Hayes, 2017; Tibbetts vd., 2017; Chen vd., 2019; Xia vd., 2019). Bu oranlara göre; alg türlerinin; tahıllar
(\%69-84), baklagiller (\%72-92), meyveler (\%7292) ve sebzeler (\%68-80) dahil olmak üzere yaygin olarak tüketilen diğer bitkisel protein kaynaklarıyla karşılaştırılabilir düzeyde olduğu söylenebilir (Bleakley ve Hayes, 2017). Çizelge 5'te detaylı olarak bazı alg türlerinin kuru ağırllktaki protein yüzdeleri ve kaliteleri gösterilmiştir. Gelecekteki çalışmalar, alg proteinlerinin ekstraksiyonu ve saflaştırılması üzerinde daha detaylı araştırmalar yaparak, alglerin bilinirliğini ve kullanımını yaygınlaştırabilir.

Çizelge 4. Bazı tahılların ve baklagillerin besin ögesi içerikleri (McKevith, 2004; Sarığlu ve Velioğlu, 2018)

\begin{tabular}{|c|c|c|c|c|c|c|c|c|}
\hline Besin Ögesi & $\begin{array}{l}\text { Beyaz } \\
\text { Pirinç }\end{array}$ & $\begin{array}{l}\text { Arpa } \\
\text { (Çiğ) }\end{array}$ & Yulaf & $\begin{array}{c}\text { Beyaz } \\
\text { un }\end{array}$ & $\begin{array}{l}\text { Nohut } \\
\text { (koçbaş1) }\end{array}$ & $\begin{array}{l}\text { Mercimek } \\
\text { (Yeşil) }\end{array}$ & $\begin{array}{c}\text { Fasulye } \\
\text { (Dermason) }\end{array}$ & Bezelye \\
\hline Enerji (kkal/kj) & 383 & - & -- & & 334 & 299 & 281 & 309 \\
\hline Yağ (g) & 3.60 & 1.70 & 9.20 & 1.20 & 5.33 & 0.92 & 1.35 & 1.15 \\
\hline Protein (g) & 7.30 & - & - & - & 18.56 & 23.00 & 21.75 & 19.82 \\
\hline $\begin{array}{l}\text { Lif (çözünebilen, } \\
\text { g) }\end{array}$ & 0.40 & - & 3.80 & - & 23.03 & 25.99 & 32.17 & 23.65 \\
\hline Tiamin (mg) & 0.41 & 0.12 & 0.90 & 0.31 & 0.57 & 0.15 & 0.77 & 0.71 \\
\hline Ribofilavin (mg) & 0.02 & 0.05 & 0.09 & 0.03 & 0.16 & 0.14 & 0.18 & 0.19 \\
\hline $\begin{array}{l}\text { Niasin eşdeğerleri } \\
(\mathrm{mg})\end{array}$ & 5.80 & 4.80 & 3.40 & 3.60 & 3.10 & 4.60 & 4.10 & 3.80 \\
\hline Folat $(\mu \mathrm{g})$ & 20 & 20 & 60 & 22 & 149.70 & - & - & 101.50 \\
\hline
\end{tabular}

*100 g'daki miktarları verilmiştir. kkal: kilokalori, g:gram, kj; kilojoule, mg: miligram $\mu$ g: mikrogram

Çizelge 5. Bazı alg türlerinin protein miktarları ve kaliteleri (Reitan, 2011; Bleakley ve Hayes, 2017; Tibbetts vd., 2017; Brown vd., 2018; Chen vd., 2019; Xia vd., 2019)

\begin{tabular}{lcc}
\hline Protein Kaynağ1 & Protein (\%) & Protein Kalitesi (\%) \\
\hline Alg türleri & & \\
Chaetoceros sp. & 33.0 & 60.0 \\
Dunaliella sp. & 25.7 & 35.7 \\
Isochrysis sp. & 47.9 & 55.4 \\
Nannochloropsis sp. & 30.3 & 74.6 \\
Phaeodactylum sp. & 49.5 & - \\
Synechococcus sp. & 63.0 & 88.0 \\
Tetraselmis sp. & 30.7 & - \\
Chroococcidiopsis sp. & 60.3 & - \\
\hline
\end{tabular}


Algler, yüksek protein içeriklerinin yanı sıra fotosentetik pigment (karotenoidler ve klorofiller), sterol, çoklu doymamış yağ asitleri, vitamin, mineral, lif, polisakkarit, çeşitli enzim, peptitler ve toksinler gibi çok çeşitli bileşikleri de üretebilmektedirler. Ayrıca farmakolojik olarak, anti-kanser, antioksidan ve anti-inflamatuar aktivitelere sahiptirler (Matos vd., 2017; GómezZorita vd., 2019). Bu etkilerinden dolayı sağlığ1 olumlu yönde etkileyebilecekleri düşüncesi ile mikroalgler üzerindeki biyoteknolojik ilgi artmış durumdadır (García vd., 2017). Bu ilgi sonucunda mevcut besinlerin protein içeriklerinin mikro ve makroalgler ile zenginleştirilmesi çeşitli araştırmacılar tarafindan denenmiştir. $\mathrm{Bu}$ çalışmaların birkaçında; alglerle zenginleştirilmiş birçok besin; çölyak hastalığı için glutensiz makarna (Fradinho vd., 2019), antioksidan kapasitesi artırılmıs kurabiye (Batista vd., 2017), gluten ağının güçlendirildiği veya antioksidan kapasitesinin artırıldığ1 ekmek (Graça vd., 2018; Nunes vd, 2020) veya buğday krakeri (Batista vd., 2019), protein içeriği artırılmış İtalya ve Avrupa'ya özgü bir unlu mamul olan crostini (kızarmış küçük ekmek) (Niccolai vd., 2019), raf ömrünü artırmak için zenginleştirilmiş tam yağlı süt (Mok vd., 2016) ürünleri gibi birçok yenilikçi besin olarak yeniden üretilmiştir.

Ülkemizde ise Spirulina platensis ile zenginleştirilmiş toplam antioksidan kapasitesi ve fenolik madde miktarı yüksek yoğurt (Aydemir ve Öner, 2020) ve probiyotik içeriği yüksek beyaz peynir (Suna, 2020), protein ve fenolik madde miktar1 yüksek ekmek (Illhan vd., 2020) gibi ürünlere rastlanmaktadır fakat mikroalgler ile besin zenginleştirme araştırmaları ülkemizde oldukça sinırlıdır. Bu nedenle yaklaşan iklim ve yetersiz besin krizi düşünüldüğünde ülkemiz adına, alternatif bitkisel protein kaynakları daha fazla araştırılmalıdır.

\section{Yenilebilir Böcekler}

Son y1llarda, artan alternatif protein kaynağ 1 arayışında yenilebilir böcekler, içerdiği makro ve mikro besin ögeleri açısından oldukça fazla dikkat çekmektedir. Böceklerin makro ve mikro besin ögesi değerleri türe, bağlı bulunduğu habitata, böceğin büyüme evresine, cinsiyetine ve pişirme tekniklerine göre değişim göstermektedir. Literatürde yenilebilen böceklerin yumurta, larva, pupa ve ergin dönemlerinde protein içeriğinin \%20-70 arasında olduğu belirtilmiştir (Özkan ve Güneş, 2020).

Yenilebilir böceklerin çoğunun, insan beslenmesinde yeterli enerji ve protein alımının yanı sira esansiyel aminoasit gereksinimlerini de karşılayabileceği düşünülmektedir. Yenilebilir böcekler, yüksek kaliteli protein kaynakları olarak adlandırılabilir. Çünkü bu protein kaynaklarının esansiyel aminoasit profili \%50 ile 80 arasindadir. Ayrıca bitki proteinleri ve et proteinleri ile karşılaştırıldığında toplam protein seviyesi de daha yüksektir (Muslu, 2020).

Bireylerin beslenmesinde yer alan diğer protein kaynakları ile kıyaslandığında çoğu böcek türü, zengin besin ögesi içeriğine sahip olması nedeni ile tercih edilebilir (Çizelge 6). Aynı zamanda yenilebilir böcekler yüksek verimliliğe sahip ve çevreye en az zararı veren alternatif protein kaynaklarından biridir (Muslu, 2020).

Genellikle Asya, Afrika ve Latin Amerika başta olmak üzere dünyada yaklaşı 2 milyar insan yenilebilir böcekleri tüketmektedir (Muslu, 2020). Bu bölgelerde en s1k tüketilen böcek türleri; eşek arıs1, tırtıl, ar1 ve karıncalardır. Ayrıca çekirge, yusufçuk, cırcır böceği, yaprak böceği, ağustos böceği, termit, sinek ve diğer türler de tüketimde tercih edilmektedir (FAO, 2020b). Ülkemizde ise yenilebilir böceklerin tüketimi yaygin olarak görülmemektedir. Toplumumuzda tüketiminin kabulünün uzun zaman alabileceği düşünülmektedir fakat gelecekte meydana gelmesi olası olan iklim krizi düşünüldüğünde, zor olsa da bu konuda halkın bilinç düzeyini artıııcı çalışmalar yapılabilir.

Bunların yanı sıra, g1da endüstrisinde yenilebilir böceklerin işlenmesi sırasında oluşabilecek alerjenler, toksinler ve kontaminantlar hakkında kapsamlı herhangi bir araştırmaya rastlanmamıştır. Bu nedenle bu alanda geniş çaplı araştırmalar yapilarak, ilgili mevzuatlar geliştirilebilir. 
Çizelge 6. Bazı böcek türlerinin, seçilmiş besinler ile karşılaştırılması (Loveday, 2019; TURKOMP,

\begin{tabular}{|c|c|c|c|}
\hline & 2021) & & \\
\hline Böcek veya besin & $\begin{array}{c}\text { Protein } \\
\text { (\% kuru ağırlık) } \\
\end{array}$ & $\begin{array}{c}\text { Yağ } \\
(\% \text { kuru ağırlık })\end{array}$ & $\begin{array}{c}\text { Enerji } \\
(\mathrm{kkal} / 100 \mathrm{~g})\end{array}$ \\
\hline Coleoptera (yetişkin böcekler, larvalar) & 40.7 & 33.4 & 490.3 \\
\hline $\begin{array}{l}\text { Rhynchophorus phoenicis (hurma kurdu } \\
\text { larvalar1) }\end{array}$ & 32.9 & 36.9 & 478.9 \\
\hline Tenebrio molitor (un kurdu larvalar1) & 48.4 & 38.5 & 557.1 \\
\hline Diptera (sinekler) & 49.5 & 22.8 & 409.8 \\
\hline Hemiptera (yarım kanatlılar) & 48.3 & 30.3 & 479.0 \\
\hline Hymenoptera (karıncalar, arilar) & 46.5 & 25.1 & 484.5 \\
\hline $\begin{array}{l}\text { Oecophylla smaragdina (dokumaci } \\
\text { karinca) }\end{array}$ & 53.5 & 13.5 & - \\
\hline Isoptera (termitler) & 35.3 & 32.7 & - \\
\hline Lepidoptera (kelebekler, güveler) & 45.4 & 27.7 & 508.9 \\
\hline Bombyx mori (ipek böceği larvaları) & 61.8 & 8.8 & 389.6 \\
\hline Cirina forda (shea tırtıl) & 47.5 & 11.5 & 359.0 \\
\hline Galleria mellonella (balmumu kurtları) & 38.0 & 56.7 & 650.1 \\
\hline $\begin{array}{l}\text { Samia cynthia ricinï (ailanthus ipek } \\
\text { böceği pupas1) }\end{array}$ & 54.7 & 25.6 & 463.6 \\
\hline Odonata (yusufçuklar, kız böcekleri) & 55.2 & 19.8 & 431.3 \\
\hline $\begin{array}{l}\text { Orthoptera (cırcır böcekleri, çekirgeler, } \\
\text { çekirgeler) }\end{array}$ & 61.2 & 13.4 & 426.3 \\
\hline Acheta domesticus (kriket yetişkin) & 65.0 & 23.0 & 455.2 \\
\hline Schistocerca sp. & 61.1 & 17.0 & 427.0 \\
\hline $\begin{array}{l}\text { Sphenarium purpuracens } \\
\text { yetişkin) }\end{array}$ & 61.3 & 11.7 & 404.2 \\
\hline $\begin{array}{l}\text { Ruspolia differens (kahverengi longhorn } \\
\text { çekirge) }\end{array}$ & 44.3 & 46.2 & \\
\hline Yağsiz süt tozu & 37.3 & 0.8 & 373.8 \\
\hline Peynir altı suyu proteini izolatı & $92.0-96.1$ & $0.4-1.0$ & - \\
\hline İzole soya proteini & 92.9 & 3.6 & 353.0 \\
\hline Çiğ biftek & 81.2 & 14.1 & 454.9 \\
\hline Yumurta* & $11.9-16.5$ & $8.5-11.0$ & 140.0 \\
\hline İnek sütü tam yağlı* & 2.8 & 2.8 & 58.0 \\
\hline Beyaz peynir tam yağlı* & 16.0 & 23.6 & 309.0 \\
\hline Yoğurt tam yağl1* & 4.5 & 3.8 & 69.0 \\
\hline Bulgur* & 12.0 & 4.0 & 357.0 \\
\hline Nohut* & 18.6 & 5.3 & 334.0 \\
\hline Mercimek* & 23.0 & 0.9 & 299.0 \\
\hline
\end{tabular}

*TÜRKOMP verileri kullanılarak hesaplanmıştır. kkal: kilokalori, g:gram

Laboratuvar Ortamında Yetiştirilmiş Et

Oldukça yeni olan kültür ortamında yetiştirilmiş et, ilk olarak 2013 yllinda Maastricht Üniversitesi'nde yapılmış bir çalışmada, laboratuvarda yetiştirilen sığır hücrelerinden oluşan bir hamburger köftesi şeklinde üretilmiştir (Loveday, 2019). Bu yöntemde; canlı bir hayvandan biyopsi ile alınan iskelet kası kök hücreleri, laboratuvar ortamında çoğaltılmış, farklılaştırılmış ve yeni doku yapıları tasarlanmışıı (Kumar vd., 2017; Loveday, 2019). Laboratuvar ortamında üretilen et için yasal durum ve etiketleme gereksinimleri halen tartısılmaktadır. Gerekli alt yapı kurulduğunda ve çalışmalar 
başladığında bireylerin diğer protein kaynaklarına kiyasla nispeten laboratuvar ortaminda yetiştirilmiş eti daha kolay kabul edebileceği öngörülmektedir.

Ayrıca, literatürde diğer alternatif protein kaynaklarının kabul edilebilirliğinin araştıııldığı çalışmalarda; besin neofobisinin bu protein kaynaklarına karşı olan kabullenmeyi engellediği (Mancini vd., 2019; de Koning vd., 2020), böcek unundan elde edilen ekmeğin "tiksinti ve endişe" uyandırdığ1 (García-Segovia vd., 2020), çoğunluğun (\%89.5) yapılan herhangi bir ürünü denemeyi reddettiği (Kostecka vd., 2017), bunların yanı sıra bu protein kaynaklarından en çok bitkisel protein kaynaklarının (\%58) tercih edildiği (Grasso vd., 2019), spirulina tadına aşinalığın kabul edilebilirliği artırdığı (Grahl vd., 2020) bildirilmiştir.

\section{SONUÇ}

Günümüzde hem dünya hem de ülkemiz, artan nüfusa paralel olarak meydana gelen çevresel etkiler nedeniyle iklim kriziyle karşı karşıyadır. Bu nedenle özellikle atmosferi etkileyen sera gazı etkisini azaltıcı önlemler alınması gerekmektedir. "Sürdürülebilirlik" bu nedenle daha da önem kazanmaktadır. Yapılan çalışmalar özellikle yüksek hayvansal kaynaklı besin tüketiminin sera gazını olumsuz yönde etkilediğini göstermektedir. Bu nedenle Akdeniz tipi beslenme, vejetaryen ve vegan beslenme gibi bitkisel protein kaynakl1 besinlerin yaygin olarak tüketildiği beslenme modelleri ön plana çıkmaktadır. Bu beslenme modellerinin hem ülkemizde hem de dünyada yaygınlaştırılması gerekmektedir. Ayrıca literatürde hayvansal protein kaynaklarına alternatif olarak geliştirilmiş yeni protein kaynakları mevcuttur. $\mathrm{Bu}$ kaynaklar besin zenginleştirme çalışmaları ile yaygınlaştırılabilir ve ülkemizde de tüketimi bu sayede artırılabilir.

Bunların yanı sıra, sürdürülebilirliğin yaygınlaşması adına BM tarafindan 2021 yılı "Uluslararas1 Meyve ve Sebze Yilı" olarak ilan edilmiştir. Burada amaç sürdürülebilirliği sağlamanın yanı sıra meyve ve sebze sektörüne dikkat çekmek; insanların ve çevrenin daha sağlıklı olmasını sağlayacak bir üretim ve tüketim yaklaşımına bütüncül bir bakış açısı sağlamaktır (FAO, 2020a). Türkiye, dünya sebze üretiminde dördüncü meyve üretiminde ise beşinci sırada yer alırken; domates (TAGEM, 2019) ve kiraz ihracatında ise birinci sırada yer alarak önemli bir konumdadır (Bayram ve Öztürkcan, 2020a). Yüksek sebze ve meyve üretim potansiyeli düşünüldügünde, ülkemizin bu potansiyelini kullanarak yapacağı tanıtım faaliyetleri ve toplumu bilinçlendirme çalışmaları "sürdürülebilir beslenme" adına oldukça önemli bir firsat olabilir.

\section{ÇIKAR ÇATIŞMASI BEYANI}

Yazarların, başka kişiler ve/veya kurumlar ile çıkar çatışması bulunmamaktadır.

\section{YAZAR KATKILARI}

BC; derlemeyi planlayarak, kaynak taramas1, veri toplama ve makalenin yazımını sağlamıştır. HMB; derlemeyi planlayarak, derlemenin tasarım, kaynakların sınıflandırılması, veri işleme, analiz ve yorum ile makalenin yazımı ve literatüre kazandırılması çalışmalarını gerçekleştirmiştir. SAÖ; derlemenin planlanması, tasarımı, eleştirel incelemesi, süreçlerin denetimi ve danışmanlığını yürütmüştür. $\mathrm{BC}, \mathrm{HMB}$ ve $\mathrm{SAÖ}$ makalenin son halini okumuş ve onaylamıştır.

\section{KAYNAKLAR}

Acet, D.B. (2017). Dietary pattern-induced greenhouse gas emission and water footprint estimations in Turkey. Orta Doğu Teknik Üniversitesi Doğa ve Uygulamalı Bilimler Enstitüsü Dünya Sistem Bilimleri Anabilim Dalı Yüksek Lisans Tezi, Ankara, Türkiye, $170 \mathrm{~s}$.

Aiking, H., de Boer, J. (2020). The next protein transition. Trends Food Sci Technol, 105: 515-522. doi:10.1016/j.tifs.2018.07.008.

Akyüz, A. (2019). Yaşamsal bilinmezlik: İklim krizi ve gida. Toplum ve Hekim, 34(5): 348-355.

Arrieta, E.M., González, A.D. (2018). Impact of current, National Dietary Guidelines and alternative diets on greenhouse gas emissions in Argentina. Food Policy, 79: 58-66. doi:10.1016/j.foodpol.2018.05.003.

Aydemir, S., Öner, Z. (2020). Farklı konsantrasyonlarda Spirulina platensis eklenmiş 
yoğurtların kimyasal ve mikrobiyolojik özellikleri. SDÜ Fen Bil Enst Der, 24(3): 553-565. doi:10.19113/sdufenbed.534480.

Barilla Center For Food Nutrition (BCFN) (2010). Double pyramid: healthy food for people and sustainable for the planet. Parma, Italy. https://www.barillacfn.com/m/publications/pp -double-pyramid-healthy-diet-for-people-

sustainable-for-the-planet.pdf (Erişim Tarihi: 11.03.2021).

Batista, A.P., Niccolai, A., Bursic, I., Sousa, I., Raymundo, A., Rodolfi, L., Biondi, N., Tredici, M.R. (2019). Microalgae as functional ingredients in savory food products: application to wheat crackers. Foods, $\quad$ 8(12): 611. doi: $10.3390 /$ foods 8120611 .

Batista, A.P., Niccolai, A., Fradinhoa, P., Fragosoa, S., Bursic, I., Rodolfi, L., Biondi, N., Tredici, M.R., Sousa, I., Raymundo, A. (2017). Microalgae biomass as an alternative ingredient in cookies: Sensory, physical and chemical properties, antioxidant activity and in vitro digestibility. Algal Res, 26: 161-171. doi: 10.1016/j.algal.2017.07.017.

Bayındır Gümüş, A., Yardımcı, H. (2019). Öğrencilerin ev dişı ana öğün tüketimlerine ve antropometrik ölçümlerine göre akdeniz diyet uyumlarının incelenmesi. STED, 28(6): 397-403. doi: 10.17942/sted.629541.

Bayram, H.M., Öztürkcan, S.A. (2020a). Antosiyanince zengin kiraz grubu meyvelerin insan sağlığ çalışmalara bir bakış. İGÜS ABDER, 11: 230-254. doi: 10.38079 /igusabder.748640.

Bayram, H.M., Öztürkcan, S.A. (2020b). Gida katk1 maddelerinin mikrobiyota üzerine etkisi. GID $A, \quad$ 45(5): 1030-1046. doi: 10.15237/gida.GD20070.

Bleakley, S., Hayes, M. (2017). Algal proteins: extraction, application, and challenges concerning production. Foods, 6(5): 33. doi: $10.3390 /$ foods 6050033 .

Boehm, R., Ver Ploeg, M., Wilde, P.E., Cash, S.B. (2019). Greenhouse gas emissions, total food spending and diet quality by share of household food spending on red meat: results from a nationally representative sample of US households. Public Health Nutr, 22(10): 1794-1806. doi:10.1017/S136898001800407X.

Broekema, R., Tyszler, M., van 't Veer, P., Kok, F.J., Martin, A., Lluch, A., Blonk, H.T.J. (2020). Future-proof and sustainable healthy diets based on current eating patterns in the Netherlands. $A m$ J Clin Nutr, 112(5): 1338-1347. doi:10.1093/ ajen/nqaa217.

Brown, J.J., Das, P., Al-Saidi, M. (2018). Sustainable agriculture in the Arabian/Persian Gulf Region utilizing marginal water resources: Making the best of a bad situation. Sustainability, 10(5): 1364. doi: 10.3390/su10051364.

Chen, M.F., Zhang, Y.Y., He, M.D., Li, C.Y., Zhou, C.Z., Hong, P.Z., Qjan, Z.J. (2019). Antioxidant peptide purified from enzymatic hydrolysates of Isochrysis Zhanjiangensis and its protective effect against ethanol induced oxidative stress of HepG2 Cells. Biotechnol Bioprocess Eng, 24: 308-317. doi: 10.1007/s12257018-0391-5.

Churchward-Venne, T.A., Pinckaers, P.J.M., van Loon, J.J.A., van Loon, L.J.C. (2017). Consideration of insects as a source of dietary protein for human consumption. Nutr Rev, 75(12): 1035-1045. doi:10.1093/nutrit/nux057.

Davis, C., Bryan, J., Hodgson, J., Murphy, K. (2015). Definition of the Mediterranean Diet; a literature review. Nutrients, 7(11): 9139-9153. doi:10.3390/nu7115459.

Davis, K., Gephart, J.A., Emery, K.A., Leach, A.M., Galloway, J., D’Odorico, P. (2016). Meeting future food demand with current agricultural resources. Glob Environ Change, 39: 125-132. doi: 10.1016/j.gloenvcha.2016.05.004.

de Koning, W., Dean, D., Vriesekoop, F., Aguiar, L.K., Anderson, M., Mongondry, P., OppongGyamfi, M., Urbano, B., Luciano, C.A.G., Jiang, B., Hao, W., Eastwick, E., Jiang, Z., Boereboom, A. (2020). Drivers and inhibitors in the acceptance of meat alternatives: the case of plant and insect-based proteins. Foods, 9(9): 1292. doi:10.3390/foods 9091292 . 
Dernini, S., Berry, E.M., Serra-Majem, L., La Vecchia, C., Capone, R., Medina, F.X., ArancetaBartrina, J., Belahsen, R., Burlingame, B., Calabrese, G., Corella, D., Donini, L.M., Lairon, D., Meybeck, A., Pekcan, A.G., Piscopo, S., Trichopoulou, A. (2017). Med Diet 4.0: the Mediterranean diet with four sustainable benefits. Public Health Nutr, 20(7): 1322-1330. doi:10.1017/s1368980016003177.

Dinu, M., Abbate, R., Gensini, G.F., Casini, A., Sofi, F. (2017). Vegetarian, vegan diets and multiple health outcomes: a systematic review with meta-analysis of observational studies. Crit Rev Food Sci Nutr, 57(17): 3640-3649. doi:10.1080/10408398.2016.1138447.

Duran, S., Durmuşçelebi, E., Yalçın, M., Karmil, G., Radonciq, A. (2019). Trakya Üniversitesi İktisadi ve İdari Bilimler Fakültesi birinci ve ikinci ögretiminde okuyan öğrencilerin uyku durumları ve beslenme alışkanlıklarının karşılaştırılması. EJFM, 8(2): 78-83. doi: 10.33880/ ejfm.2019080204.

Ernstoff, A., Stylianou, K.S., Sahakian, M., Godin, L., Dauriat, A., Humbert, S., Erkman, S., Jolliet, O. (2020). Towards win-win policies for healthy and sustainable diets in Switzerland. Nutrients, 12(9): 2745. doi:10.3390/nu12092745.

FAO. (2020a). Fruit and vegetables - your dietary essentials, The International Year of Fruits and Vegetables, 2021, background paper. http://www.fao.org/documents/card/en/c/cb2 395en/\#: :text=The $\% 20$ International $\% 20$ Year $\% 20$ of $\% 20$ Fruits $\% 20$ and $\% 20$ Vegetables $\% 20202$ $1 \% 20$ (IYFV) $\% 2$ C,the $\% 20$ contribution $\% 20$ of $\% 2$ Ofruit $\% 20$ and (Erişim Tarihi: 10.03.2021).

FAO. (2020b). Insects for food and feed. The contribution of insects to food security, livelihoods and the environment. http://www.fao.org/edible-insects/en/ (Erişim tarihi: 08.01.2020).

Fradinho, P., Niccolai, A., Soares, R., Rodolfi, L.,Biondi, N., Tredici, M.R., Sousa, I., Raymundo, A. (2019). Effect of Arthrospira platensis (spirulina) incorporation on the rheological and bioactive properties of gluten-free fresh pasta.
Algal Res, $\quad 45: \quad 101743$. doi:10.1016/j.algal.2019.101743.

Fresán, U., Sabaté, J. (2019). Vegetarian Diets: Planetary health and its alignment with human health. Adv Nutr, 10(Suppl_4): 380-388. doi:10.1093/advances/nmz019.

García-Segovia, P., Igual, M., Martínez-Monzó, J. (2020). Physicochemical properties and consumer acceptance of bread enriched with alternative proteins. Foods, 9(7): 933. doi:10.3390/ foods 9070933.

García, J.L., de Vicente, M., Galán, B. (2017). Microalgae, old sustainable food and fashion nutraceuticals. Microb Biotechnol, 10(5): 1017-1024. doi:10.1111/1751-7915.12800.

Gómez-Zorita, S., Trepiana, J., González-Arceo, M., Aguirre, L., Milton-Laskibar, I., González, M., Eseberri, I., Fernández-Quintela, A., Portillo, M.P. (2019). Anti-obesity effects of microalgae. Int J Mol Sci, 21(1): 41. doi:10.3390/ijms21010041.

Graça, C., Fradinho, P., Sousa, I., Raymundo, A. (2018). Impact of Chlorella vulgaris on the rheology of wheat flour dough and bread texture. LWT, 89: 466-474. doi: 10.1016/ j.lwt.2017.11.024.

Grahl, S., Strack, M., Mensching, A., Mörlein, D. (2020). Alternative protein sources in Western diets: Food product development and consumer acceptance of spirulina-filled pasta. Food Qual Prefer, 84: 103933. doi: 10.1016/j.foodqual. 2020.103933.

Grasso, A. C., Hung, Y., Olthof, M.R., Verbeke, W., Brouwer, I.A. (2019). Older consumers' readiness to accept alternative, more sustainable protein sources in the european union. Nutrients, 11(8): 1904. doi: 10.3390/nu11081904.

Green, R. F., Joy, E. J. M., Harris, F., Agrawal, S., Aleksandrowicz, L., Hillier, J., Macdiarmid, J.I., Milner, J., Vetter, S. H., Smith, P., Haines, A., Dangour, A.D. (2018). Greenhouse gas emissions and water footprints of typical dietary patterns in India. Sci Total Environ, 643: 1411-1418. doi:10.1016/j.scitotenv.2018.06.258.

Grosso, G., Fresán, U., Bes-Rastrollo, M., Marventano, S., Galvano, F. (2020). 
Environmental impact of dietary choices: role of the Mediterranean and other dietary patterns in an Italian cohort. Int J Environ Res Public Health, 17(5): 1468. doi:10.3390/ijerph17051468.

Hendrie, G.A., Baird, D., Ridoutt, B., Hadjikakou, M., Noakes, M. (2016). Overconsumption of energy and excessive discretionary food intake inflates dietary greenhouse gas emissions in Australia. $\quad$ Nutrients, $\quad 8(11)$ : 690. doi:10.3390/nu8110690.

Hendrie, G.A., Ridoutt, B.G., Wiedmann, T.O., Noakes, M. (2014). Greenhouse gas emissions and the Australian diet--comparing dietary recommendations with average intakes. Nutrients, 6(1): 289-303. doi:10.3390/nu6010289.

İlhan, E., Büyükizgi, A. N., Ermiş, E. (2020). Mavi-yeşil alg Spirulina platensis'in buğday ekmeğinde kimyasal, duyusal ve antifungal etkisi. Gida ve Yem Bilimi Teknolojisi Dergisi, 0(24): 22-29. ISSN: 1303-3107.

Kostecka, J., Konieczna, K., Cunha, L.M. (2017). Evaluation of insect-based food acceptance by representatives of Polish consumers in the context of natural resources processing retardation. $J$ Ecol Eng, 18(2): 166-174. doi:10.12911/22998993/68301.

Köseoğlu, S.Z. (2019). Bazı tahıl ürünlerinin protein kalite indeksinin protein sindirilebilirliği düzeltilmiş amino asit skoru (PDCAAS) metodu ile belirlenmesi. EJOSAT, 17: 477-482. doi: 10.31590/ejosat.633638.

Kumar, P., Chatli, M.K., Mehta, N., Singh, P., Malav, O.P., Verma, A.K. (2017). Meat analogues: health promising sustainable meat substitutes. Crit Rev Food Sci Nutr, 57(5): 923-932. doi:10.1080/10408398.2014.939739.

Loveday, S.M. (2019). Food proteins: technological, nutritional, and sustainability attributes of traditional and emerging proteins. Annu Rev Food Sci Technol, 10: 311-339. doi:10.1146/annurev-food-032818-121128.

Mancini, S., Sogari, G., Menozzi, D., Nuvoloni, R., Torracca, B., Moruzzo, R., Paci, G. (2019). Factors predicting the intention of eating an insect-based product. Foods, 8(7): 270. doi:10.3390/foods 8070270 .

Matos, J., Cardoso, C., Bandarra, N.M., Afonso, C. (2017). Microalgae as healthy ingredients for functional food: a review. Food Funct, 8(8): 2672 2685. doi:10.1039/c7fo00409e.

McKevith, B. (2004). Nutritional aspects of cereals. Nutr Bull, 29(2): 111-142. doi: 10.1111/j.1467-3010.2004.00418.x.

Meltzer, H.M., Brantsæter, A.L., Trolle, E., Eneroth, H., Fogelholm, M., Ydersbond, T.A., Birgisdottir, B.E. (2019). Environmental sustainability perspectives of the Nordic diet. Nutrients, 11(9): 2248. doi:10.3390/nu11092248.

Meyer, N., Reguant-Closa, A. (2017). "Eat as if you could save the planet and win!" sustainability integration into nutrition for exercise and sport. Nutrients, 9(4): 412. doi:10.3390/nu9040412.

Mogensen, L., Hermansen J.E., Trolle, E. (2020). The climate and nutritional impact of beef in different dietary patterns in Denmark. Foods, 9(9): 1176. doi:10.3390/ foods 9091176 .

Mok, IK., Yoon, J.R., Pan, C.H., Kim, S.M. (2016). Development, quantification, method validation, and stability study of a novel fucoxanthin-fortified milk. J Agric Food Chem, 64(31): 6196-6202. doi:10.1021/acs.jafc.6b02206.

Murakami, K., Livingstone, M.B.E. (2018). Greenhouse gas emissions of self-selected diets in the UK and their association with diet quality: is energy under-reporting a problem? Nutr J, 17(1): 27. doi:10.1186/s12937-018-0338-x.

Muslu, M. (2020). Sağlı̆̆ın geliştirilmesi ve sürdürülebilir beslenme için alternatif bir kaynak: yenilebilir böcekler. GIDA, 45(5): 1009-1018. doi: 10.15237/gida.GD20071.

Naja, F., Jomaa, L., Itani, L., Zidek, J., El Labban, S., Sibai, A.M., Hwalla, N. (2018). Environmental footprints of food consumption and dietary patterns among Lebanese adults: a cross-sectional study. Nutr J, 17: 85. doi:10.1186/s12937-0180393-3.

NASA (2021). Global Climate Change, vital signs of the planet. https://climate.nasa.gov/vital- 
signs/global-temperature) (Erişim Tarihi: 10.03.2021).

Nelson, M.E., Hamm, M.W., Hu, F.B., Abrams, S.A., Griffin, T.S. (2016). Alignment of healthy dietary patterns and environmental sustainability: a systematic review. Adv Nutr, 7(6): 1005-1025. doi:10.3945/an.116.012567.

Niccolai, A., Venturi, M., Galli, V., Pini, N., Rodolfi, L., Biondi, N., D'Ottavio, M., Batista, A.P., Raymundo, A., Granchi, L., Tredici, M.R. (2019). Development of new microalgae-based sourdough "crostini": functional effects of Arthrospira platensis (spirulina) addition. Sci Rep, 9: 19433. doi:10.1038/s41598-019-55840-1.

Nunes, M.C., Graça, C., Vlaisavljevićb, S., Tenreiroc, A., Sousaa, I., Raymundo, A. (2020). Microalgal cell disruption: effect on the bioactivity and rheology of wheat bread. Algal Res, 45: 101749. doi: 10.1016/j.algal.2019.101749.

Özkan, M., Güneş, E. (2020). Alternatif gıda kaynağ1 olarak yenilebilir böceklerin kullanımına dair bakış açılarının değerlendirilmesi. JOTAGS, 8(2): 839-851. doi:10.21325/jotags.2020.583.

Parca, F., Koca, Y.O., Aydin, U. (2018). Nutritional and antinutritional factors of some pulses seed and their effects on human health. Int J Sec Metabolite, 5(4): 331-342. doi: 10.21448/ijsm.488651.

Pekcan, A.G. (2019). Sürdürülebilir beslenme ve beslenme örüntüsü: bitkisel kaynaklı beslenme. Bes Diy Der, 47(2): 1-10. doi:10.33076/2019.BDD.1268.

Perçin, D. (2017). Paris Zirvesi'nden Bonn Zirvesi'ne Küresel İklim Zirveleri. http://jusgentiumint.org/wp-content/uploads/ 2017/06/bonn-zirvesi.pdf (Erişim Tarihi: 11.03.2021).

Reitan, K.I. (2011). Digestion of lipids and carbohydrates from microalgae (Chaetoceros muelleri Lemmermann

and Isochrysis aff. galbana clone T-ISO) in juvenile scallops (Pecten maximus L.). Aquac Res, 42(10): 1530-1538. doi:10.1111/j.1365-2109.2010.02745. $\mathrm{x}$.
Ruini, L.F., Ciati, R., Pratesi, C.A., Marino, M., Principato, L., Vannuzzi, E. (2015). Working toward healthy and sustainable diets: The "Double Pyramid Model" developed by the barilla center for food and nutrition to raise awareness about the environmental and nutritional impact of foods. Front Nutr, 2: 9. doi:10.3389/fnut.2015.00009.

Sahruzaini, N.A., Rejab, N.A., Harikrishna, J.A., Khairul Ikram, N.K., Ismail, I., Kugan, H.M., Cheng, A. (2020). Pulse crop genetics for a sustainable future: where we are now and where we should be heading. Front Plant Sci, 11: 531. doi:10.3389/fpls.2020.00531.

Sarıŏlu, G., Velioğlu, Y. (2018). Baklagillerin bileşimi. Akademike Gıda, 16(4): 483-496. doi:10.24323/akademik-gida.505547.

Satija, A., Hu, F.B. (2018). Plant-based diets and cardiovascular health. Trends Cardiovasc Med, 28(7): 437-441. doi:10.1016/j.tcm.2018.02.004.

Ścieszka, S., Klewicka, E. (2019). Algae in food: a general review. Crit Rev Food Sci Nutr, 59(21): 3538-3547. doi:10.1080/10408398.2018.1496319.

Sjörs, C., Hedenus, F., Sjölander, A., Tillander, A., Bälter, K. (2017). Adherence to dietary recommendations for Swedish adults across categories of greenhouse gas emissions from food. Public Health Nutr, 20(18): 3381-3393. doi: 10.1017/S1368980017002300.

Spiker, M., Reinhardt, S., Bruening, M. (2020). Academy of Nutrition and Dietetics: Revised 2020 Standards of Professional Performance for Registered Dietitian Nutritionists (competent, proficient, and expert) in sustainable, resilient, and healthy food and water systems. I Acad Nutr Diet, 120(9): 1568-1585. doi:10.1016/j.jand. 2020.05.010.

Sranacharoenpong, K., Soret, S., Harwatt, H., Wien, M., Sabaté, J. (2015). The environmental cost of protein food choices. Public Health Nutr, 18(11): 2067-2073. doi:10.1017/ S1368980014002377.

Sugimoto, M., Murakami, K., Fujiwara, A., Asakura, K., Masayasu, S., Sasaki, S. (2020). Association between diet-related greenhouse gas 
emissions and nutrient intake adequacy among Japanese adults. PLoS One, 15(10): e0240803. doi:10.1371/journal.pone.0240803.

Suna, G. (2020). Spirulina platensis ve Chlorella vulgaris ile zenginleştirilmiş probiyotik beyaz peynir üretiminin araştırılması. Bursa Uludağ Üniversitesi Fen Bilimleri Enstitüsü Gıda Mühendisliği Anabilim Dalı Yüksek Lisans Tezi, Bursa, $219 \mathrm{~s}$.

TAGEM. (2019). Yaş meyve ve sebze çalıştayı. https://www.tarimorman.gov.tr/TAGEM/Belg eler/Duyurular $/ \% \mathrm{C} 3 \% 87 \mathrm{Al} \% \mathrm{C} 4 \% \mathrm{~B} 1 \% \mathrm{C} 5 \% 9 \mathrm{Ft}$ ay\%20Raporu\%20son\%20hali.pdf (Erişim Tarihi: 12.03.2021).

Tibbetts, S.M., Yasumaru, F., Lemos, D. (2017). In vitro prediction of digestible protein content of marine microalgae (Nannochloropsis granulata) meals for Pacific white shrimp (Litopenaeus vannamei) and rainbow trout (Oncorhynchus mykiss). Algal Res, 21: 76-80. doi: 10.1016/j.algal.2016.11.010.

Tilman, D., Clark, M. (2014). Global diets link environmental sustainability and human health. Nature, $\quad$ 515(7528): 518-522. doi:10.1038/nature13959.

Tseng, A.A. (2020). Equivalent reduction in greenhouse gas emissions by Mahayana buddhists practicing vegetarian diets. J Relig Health, 59(1): 598-613. doi:10.1007/s10943-017-0511-0.

TURKOMP (2021). Ulusal gida kompozisyon veri taban1 http://www.turkomp.gov.tr/ database?type $=$ foods (Erişim Tarihi: 12.03.2021).

T.C. Sağllk Bakanlığı (2019). Türkiye Beslenme ve Sağlık Araştırması 2017. https://hsgm.saglik.gov.tr/depo/birimler/saglikl i-beslenme-hareketli-hayat-

db/Yayinlar/kitaplar/TBSA_RAPOR_KITAP_ 20.08.pdf (Erişim tarihi: 08.01.2020).

TÜíK (2020). Sera gazı emisyon istatistikleri, 1990-2018. https://tuikweb.tuik.gov.tr/ PreHaberBultenleri.do?id=33624 (Erişim Tarihi: 26.01.2021).

United Nations (2016). Sustainable development goals. https://www.un.org/sustainabledevelopment/ (Erişim Tarihi: 22.01.2021).

United Nations (2019). World population prospects 2019. https://population.un.org/wpp/ Publications/Files/WPP2019_DataBooklet.pdf (Erişim Tarihi: 10.03.2021).

United Nations (2021). Sustainable development goals, goals 2: zero hunger. https://www.un.org/ sustainabledevelopment/hunger/ (Erişim Tarihi: 27.01.2021).

Vázquez-Rowe, I., Larrea-Gallegos, G., Villanueva-Rey, P., Gilardino, A. (2017). Climate change mitigation opportunities based on carbon footprint estimates of dietary patterns in Peru. PLoS One, 12(11): e0188182. doi:10.1371/ journal.pone.0188182.

Watts, N., Amann, M., Arnell, N., Ayeb-Karlsson, S., Beagley, J., Belesova, K., et al. (2020). The 2020 report of The Lancet Countdown on health and climate change: responding to converging crises. Lancet, 397(10269): 129-170. doi:10.1016/S01406736(20)32290-X.

Widmer, J.R., Flammer, A.J., Lerman, L.O., Lerman, A. (2015). The Mediterranean diet, its components, and cardiovascular disease. $A m \mathrm{~J}$ Med, 128(3): 229-238. doi:10.1016/j.amjmed. 2014.10.014.

Xia, E., Zhai, L., Huang, Z., Liang, H., Yang, H., Song, G., Li, W., Tang, H. (2019). Optimization and identification of antioxidant peptide from Underutilized Dunaliella salina protein: extraction, in vitro gastrointestinal digestion, and fractionation. Biomed Res Int, 2019: 6424651. doi:10.1155/2019/6424651.

Zurek, M., Hebinck, A., Leip, A., Vervoort, J., Kuiper, M., Garrone, M., Havlik, P., Heckelei, T., Hornborg, S., Ingram, J., Kujisten, A., Shutes, L., Gelejinse J.M., Terluin, I., van't Veer, P., Wijnands, J., Zimmermann, A.,Achterbosch, T. (2018). Assessing sustainable food and nutrition security of the EU food system-an integrated approach. Sustainability, 10: 4271. doi:10.3390/su10114271. 